\title{
ANCIENT EL NIÑO EVENTS, HUMAN ADAPTATION, AND ECOLOGICAL TRANSFORMATIONS: EARLY FORMATIVE PERIOD (2400-1450 B.C.) OCCUPATIONS IN SOUTHERN COASTAL ECUADOR
}

\author{
ANTIGUOS EVENTOS DE EL NIÑO, ADAPTACIÓN HUMANA Y \\ TRANSFORMACIONES ECOLÓGICAS: PERÍODO FORMATIVO TEMPRANO \\ (2400-1450 AC) OCUPACIONES EN LA COSTA SUR DE ECUADOR
}

\author{
John E. Staller*
}

\begin{abstract}
El Niño-Southern Oscillation is a warming of surface sea temperatures in the eastern Pacific Ocean. Such climatic and oceanographic perturbations have dramatic impacts upon human adaptation and sociocultural development. Evidence multidisciplinary Artificial a mound of dirt in the ceremonial center of Valdivia The Emerancia have documented the abandonment of the site in relation to the El Niño phenomenon. The intial site abandonment was in response to intense or mega event dated to $2150 \mathrm{BC}$, associated withe the formation of the beach, singing fossil reoccupation C14 and dated ca 2200-1450 BC and final abandonment dated to 1450 B.C. Final abandonment is associated with an earthquake and a short-lived reoccupation. Data from excavation, regional settlement patterns and shellfish frequencies are presented to determine whether repeated and final site abandonment was related to El Niño. Results indicate widespread environmental degradation and geomorphological changes to the surrounding coastline were related to El Niño, and that it was clearly a factor to sociocultural development and adaptive responses. These data explore chronology, assess the intensities, and measure the effects of ancient El Niño events upon pre-Hispanic occupations this ceremonial center and pre-Hispanic occupations along the Arenillas River valley, El Oro Province, Ecuador.
\end{abstract}

Key words: El Niño, Andes, coastal geology, geomorphology, extinctions.

El Niño-Oscilación del Sur es un calentamiento de las temperaturas de la superficie del mar en el océano Pacífico oriental. Tales perturbaciones climáticas y oceanográficas tienen un impacto dramático sobre la adaptación humana y el desarrollo sociocultural. Evidencias multidisciplinarias de un montículo de tierra artificial en el centro ceremonial La Emerancia de Valdivia han documentado que el abandono inicial del sitio fue en respuesta a un intenso megaevento fechado ca 2150 a.C., asociado con la formación de la playa, canto fósil, C14 y reocupación de fecha ca 2200-1450 a.C. y con abandono final fechado ca 1450 a.C. El abandono final está asociado con un terremoto y una reocupación de corta duración. Los datos de la excavación, los patrones de asentamiento regionales y las frecuencias de los mariscos se presentan para determinar si repetida y último abandono del sitio se relaciona con El Niño. Los resultados indican que la degradación generalizada del medio ambiente y de los cambios geomorfológicos en la costa de los alrededores estaban relacionados con El Niño, y que era claramente un factor de desarrollo sociocultural y las respuestas de adaptación. Estos datos exploran cronología, evaluar las intensidades, y medir los efectos de los antiguos eventos de El Niño sobre las ocupaciones prehispánicas de este centro ceremonial y ocupaciones prehispánicas a lo largo del valle del río Arenillas, provincia de El Oro, Ecuador.

Palabras claves: El Niño, los Andes, geología costera, geomorfología, extinciones.

\section{Introduction}

El Niño/Southern Oscillation is related to changes in oceanic currents and trade winds, characterized by a general warming of surface sea temperatures along the Eastern Pacific, and a lessening or reversing of northeast trade winds, bringing warm humid air over coastal South America (Philander 1998:108; Fagan 1999:119-138). These climatic and oceanographic alterations create a reduction of upwelling cold waters along the west coast of South America. These climatic changes result in dramatic perturbations to maritime and terrestrial flora and fauna and, consequently, human adaptation. El Niño phenomenon in its current manifestations has its origins around c. 5800 years ago (Sandweiss 1986, 2003; Sandweiss et al. 2009; Andrus et al. 2008). When El Niño is particularly extreme or intense, as

* The Field Museum, Department of Anthropology, Research Associate, Estados Unidos. Correo electrónico: jstaller@ earthlink.net 
the $1983 / 84$, or $1997 / 98$ events, they are referred to as Mega El Niño, which are broadly differentiated by intensity and duration, or a combination of both (Moseley 1987:7; Moy et al. 2002). The following study presents multidisciplinary evidence consisting of both regional survey and excavations, as well as radiocarbon and AMS dates, geomorphological evidence and statistical analysis of minimum number of individuals (MNI) of marine shell excavated from natural stratigraphic layers as well as arbitrary increments, to determine the approximate antiquity and duration of El Niño events. These data address their possible relationship to widespread changes in human adaptation and the natural landscape and geomorphology between c. 2200 and 1450 B.C.

These multiple lines of evidence are from archaeological research in southern El Oro Province, Ecuador (Figure 1). Excavation and regional survey uncovered indications of regional perturbations, involving the ecology, geology, geomorphology, and regional settlement patterning related to $\mathrm{El} \mathrm{Niño/}$ Southern Oscillation (Staller 1994:131-153, 211$232,335-347)^{1}$. Shell counts of minimum number of individuals (MNI) provide a basis for assessing the times of occurrence, intensity, and duration, as well as how such climatic events effected human adaptation (see also Staller 1992/93, 1996, 2000, 2001b). There is evidence for a general trend of increased frequency of El Niño events that in some instances changed the climate and coastal habitats permanently. These El Niño-induced alterations required major adaptive changes and short-term increased dependence upon certain seasonally specific resources and suggest the long-term cultural response to such ecological and geomorphological transformations favored flexibility or increased diet breadth rather than specialization and/or dependence upon particular resources (Staller 1994, 2001a, 2001b; see Binford 1989, 2001).

\footnotetext{
Excavations at La Emerenciana and regional survey and excavations along the lower Arenillas River were under the direction of the author over a period of twenty-one months. Archaeological research was under the auspices of the Museo Antropológico in Guayaquil, Ecuador and Department of Anthropology, Southern Methodist University, Dallas, Texas. The project was fully funded by a Fulbright research scholarship in 1988 and research grant in 1989, under the auspices of the Fulbright Association and the Institute for International Education (IIE) in Washington DC (Staller 1994).
}

\section{Ocean Currents, Trade Winds, Sea Surface Temperatures and Climate}

Oceanographic research has indicated that the El Niño phenomenon is related in part to changes in oceanic trade winds and the maintenance of a westward rising water gradient across the eastern Pacific (Wrtki 1979, 1982; Wrtki et al. 1976; Philander 1989; McPhaden and Picaut 1990). During a normal dry season, the trade winds create an upwelling or an upward flow of cold deep water along the eastern equatorial Pacific. During an El Niño, trade winds weaken or reverse and cold sea surface temperatures (SST) are replaced by warm surface water along the eastern Pacific (McPhaden 1999:950-951; Moseley et al. 1981). Warmer SST is initially apparent on offshore areas in the Santa Elena Peninsula (Rasmussen 1985:168; McPhaden 1999:figure 3; McPhaden and Picaut 1990).

Cold SSTs are ordinarily accompanied by a strong, cool breeze that slightly lowers the air temperatures for most of the year producing moisture in the form of a dense fog or "garúa" (Thayer and Barber 1984:6). Cloud forests in the lower slopes of the Andes trap and recycle huge quantities of moisture in the form of clouds moving in off the ocean, even during the driest months (Parker and Carr 1992:17). The moisture generated by cloud forests maintains a high water table and year-round flow of the coastal streams, which have obvious implications for long-term human adaptation and population density. In coastal Peru, the garúa nourishes lush patches of vegetation, or "fog meadows", called lomas formations, which are greenest between April and December (Lanning 1965:68). Such islands of vegetation in a sea of desert sand were important to early human adaptation and ecological diversity, and their geographic distribution is greatly dependent upon El Niño cycles (Lanning 1965:70-72). Although lomas have yet to be identified in coastal Ecuador, Edwin Ferdon (1950:61) mentions seeing, "the existence of isolated continually moist, hill top forest cover" near Manta in northern Manabí Province. If lomas existed further to the south of Manta, they would certainly have been modified by habitations or agricultural practices.

One of the primary factors affecting climate and the onset of El Niño is a change in the prevailing trade winds and resultant SST (McPhaden 1999:950; Vuille et al. 2000). Trade winds along the eastern Pacific blow from the southwest to the east 


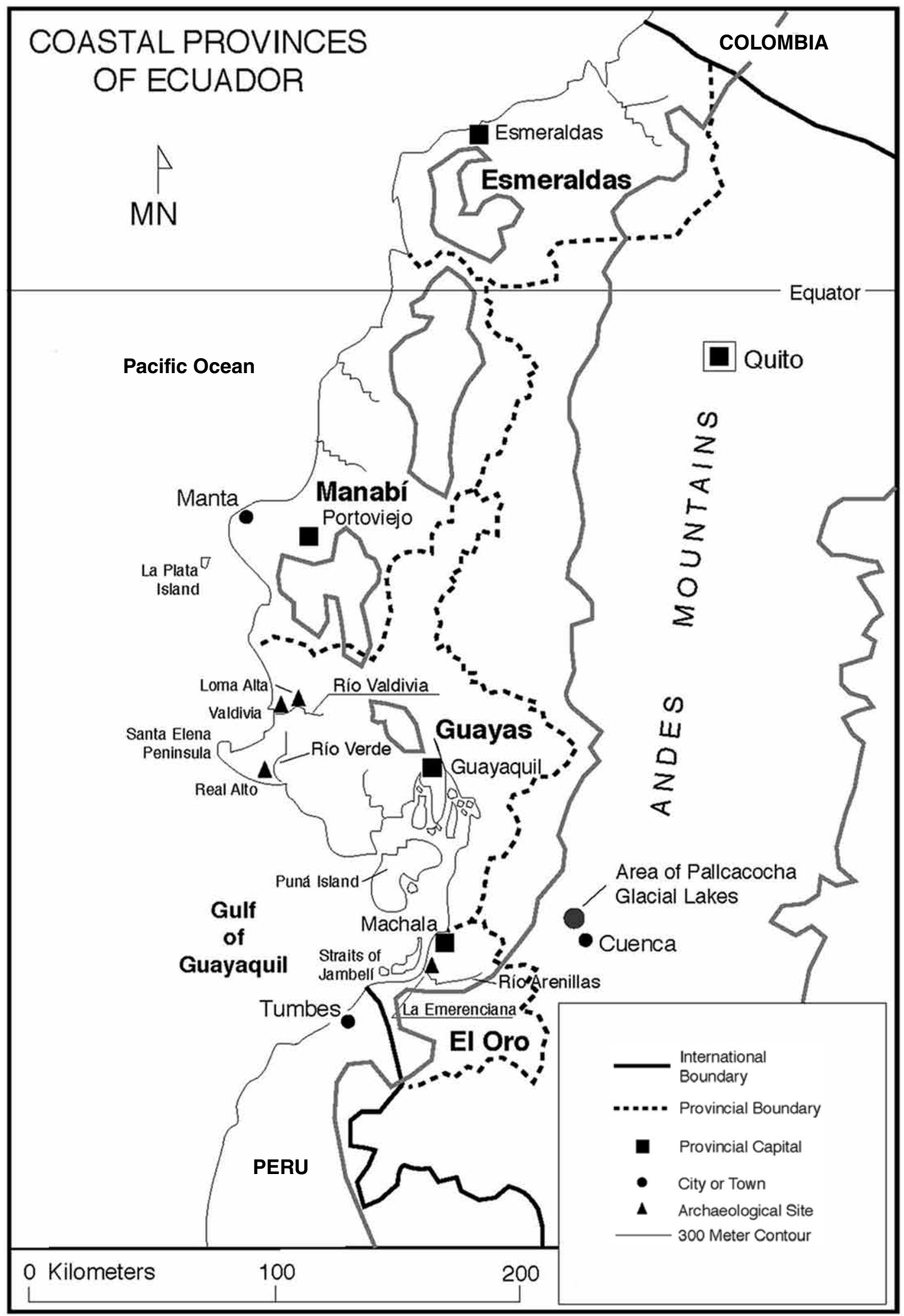

Figure 1. Coastal provinces of Ecuador showing the Gulf of Guayaquil, Straits of Jambelí and Valdivia sites, modern cities, as well as towns mentioned in the text. 
during the dry season, and during El Niño weaken or falter due to decreased variations in land and sea temperatures (Ferdon 1950:37; Wrtki et al. 1976; McPhaden 1999). When trade winds subside, the ocean responds with dramatic temperature increases, setting altered currents into motion (Thayer and Barber 1984:4; Vuille et al. 2000). A rise in sea level sets the stage for high tides that can produce large-scale erosion (Thayer and Barber 1984:4; Cane 1983:1190-1191; Moreano 1984; Wrtki 1982).

Increases in precipitation can produce fluvial erosion, causing significant increases in sediment load in the stream channels resulting in large-scale modification of the coastline and sudden and dramatic increases in mean water level for periods of several weeks or even months (Arntz 1986; Craig and Shimada 1986; Wells 1987; McPhaden 1999). In low energy tidal-dominated settings such conditions can produce flash floods and increased river discharges that may radically alter the landscape (Thayer and Barber 1984:4; Cane 1983:1190-1191; Caviedes 1975:Figures 2, 4; Wells 2001:150; Keefer et al. 2003; Sandweiss et al. 2007).

El Niño related sea level rise occurs during high "spring tides" (marejadas maretazos), and accompanying waves often result in mass destruction along the littoral (Arntz 1986:7). Under certain conditions, surge waves can completely engulf the back barrier and severely erode island barriers and shallow reefs. As the storm passes or the tide ebbs, the increasing height differential between these merging bodies of water causes sudden and massive seaward discharges called "storm surge ebb-residual flow," which create new channels and widen old breaches (Carter 1988:235; Wells 2001:152-153, 161). Such discharges are critical in fashioning the barrier coast and determining patterns of sediment dispersal across the adjacent shelf (Hayes 1975, 1979; Swift 1975, 1976; Swift et al. 1985). Archaeological and stratigraphic evidence at La Emerenciana indicates final site abandonment at around 1450 B.C. was related to such dynamic climatic conditions during a major El Niño event (Staller 1994).

Areas along the eastern equatorial Pacific between $1^{\circ}$ to $3^{\circ}$ South Latitude usually experience an incremental increase in precipitation during El Niño and decreases in duration and intensity north and south of $5^{\circ}$ South Latitude (McPhaden 1999:950-951; Rodbell et al. 1999:519; Vuille et al. 2000:2520; Moy et al. 2002:163). The intensity and duration of El Niño cycles are irregular, with mega events occurring roughly two to four times in a century (Moseley 1987:7). The 1983/84 Mega-El Niño was followed by another Mega event during 1997/98, but these were distinct in their effects and duration. El Niños vary in intensity and duration and occur in two to seven year cycles (Kerr 1998). The physics of the phenomenon are complex and represent a worldwide weather perturbation (Sandweiss 2003; Sandweiss et al. 1996, 2009).

The climate in coastal El Oro is classified as "semi-arid," distinguished by a marked annual variation of wet and dry seasons (Ferdon 1950:52, Figure 17; Momsen 1968). The nine-month dry season lasts from May to January (Tables 1-2). However, orographic rainfall occurs in higher elevations in the sierra and highland streams drain into the Jambelí Estuary, maintaining a constant supply of fresh water to the lowlands (Ferdon 1950:43; Murray et al. 1975:346). Average annual precipitation is insufficient to sustain a year-round agricultural economy (Staller 1994; Tykot and Staller 2002). Contemporary agriculture is generally by floodwater farming and small-scale pot irrigation. The coastal savanna between the Arenillas and Buenavista Rivers is low relief topographically and does not lend itself to irrigation (Staller 1994). Regional survey indicates that pre-Hispanic irrigation canals or raised fields are completely absent. The driest subregion is directly adjacent to the Peruvian frontier, the coastal savanna or Pampas de Cayanca (Figure 2).

Average annual precipitation is highly variable, more than $90 \%$ occurring between May and July, the rainy season (Ferdon 1950:figure 17; Momsen 1968:92, 96; Wernstedt 1972:121; Cañadas-Cruz 1983:25; Staller 2001a:table III). Regional variability in rainfall between the seashore and further inland is evident by a $30 \%$ reduction in average annual rates between Puerto Bolivar and Machala, an overland distance of less than $10 \mathrm{~km}$, and a $75 \%$ reduction between Puerto Bolivar and Zorritos at the Peruvian frontier (Table 1). Climatic conditions closely approximate other regions of the Gulf of Guayaquil such as the southeastern portion of Puná Island and inland regions of the Santa Elena Peninsula (Momsen 1968:96, table 1; Troll 1968). Annual temperatures average $24.7^{\circ} \mathrm{C}$ and range from $27^{\circ}$ to $35^{\circ} \mathrm{C}$ in the northern part of the Gulf near Guayaquil and $22.7^{\circ}$ to $27.1^{\circ} \mathrm{C}$ in southern coastal El Oro (Wolf 1892:389; Svenson 1946:405; Wernstedt 1972:121; Staller 2001a:table IV). A $4^{\circ} \mathrm{C}$ 
Table 1. Average annual rainfall (mm), coastal El Oro Province, Ecuador.

\begin{tabular}{|c|c|c|c|c|c|c|c|c|c|c|c|c|}
\hline \multirow{2}{*}{$\begin{array}{l}\text { Weather } \\
\text { Station }\end{array}$} & \multicolumn{12}{|c|}{ Months } \\
\hline & $\mathrm{J}$. & F. & M. & A. & M. & J. & $\mathrm{J}$. & A. & S. & O. & $\mathrm{N}$. & D. \\
\hline Machala & 109.9 & 156.9 & 177 & 105.9 & 46.9 & 19.0 & 17.0 & 20.0 & 16.0 & 18.0 & 9.9 & 11.9 \\
\hline P. Bolivar & 66.0 & 134.8 & 160 & 87.9 & 11.9 & 13.9 & 9.9 & 8.8 & 9.9 & 13.9 & 7.1 & 10.9 \\
\hline Zorritos & 18.0 & 56.1 & 33 & 17.0 & 0.0 & 1.0 & 1.0 & 1.0 & 0.0 & 0.0 & 1.0 & 1.0 \\
\hline
\end{tabular}

Average Annual Precipitation: Machala (708.9) P. Bolivar (505.9) Zorritos (129.0) (after Wernstedt 1972).

Table 2. Average annual temperatures $\left({ }^{\circ} \mathrm{c}\right)$ coastal El Oro Province, Ecuador

\begin{tabular}{|c|c|c|c|c|c|c|c|c|c|c|c|c|}
\hline \multirow{2}{*}{$\begin{array}{l}\text { Weather } \\
\text { Station }\end{array}$} & \multicolumn{12}{|c|}{ Months } \\
\hline & $\mathrm{J}$. & F. & M. & A. & M. & $\mathrm{J}$. & J. & A. & $\mathrm{S}$. & O. & N. & D. \\
\hline Machala & 26.0 & 26.2 & 26.5 & 26.6 & 26.0 & 24.2 & 23.3 & 22.7 & 23.0 & 23.2 & 23.7 & 25.2 \\
\hline P. Bolivar & 25.8 & 26.5 & 26.6 & 26.5 & 25.5 & 23.8 & 23.2 & 22.7 & 23.0 & 23.2 & 23.7 & 25.0 \\
\hline Zorritos & 26.6 & 26.8 & 27.1 & 26.1 & 25.6 & 24.2 & 23.0 & 22.7 & 22.7 & 23.2 & 23.3 & 25.1 \\
\hline
\end{tabular}

Annual Average Temperatures: Machala $\left(24.7^{\circ}\right)$ P. Bolivar $\left(24.7^{\circ}\right)$ Zorritos $\left(24.7^{\circ}\right)$ (after Wernstedt 1972).

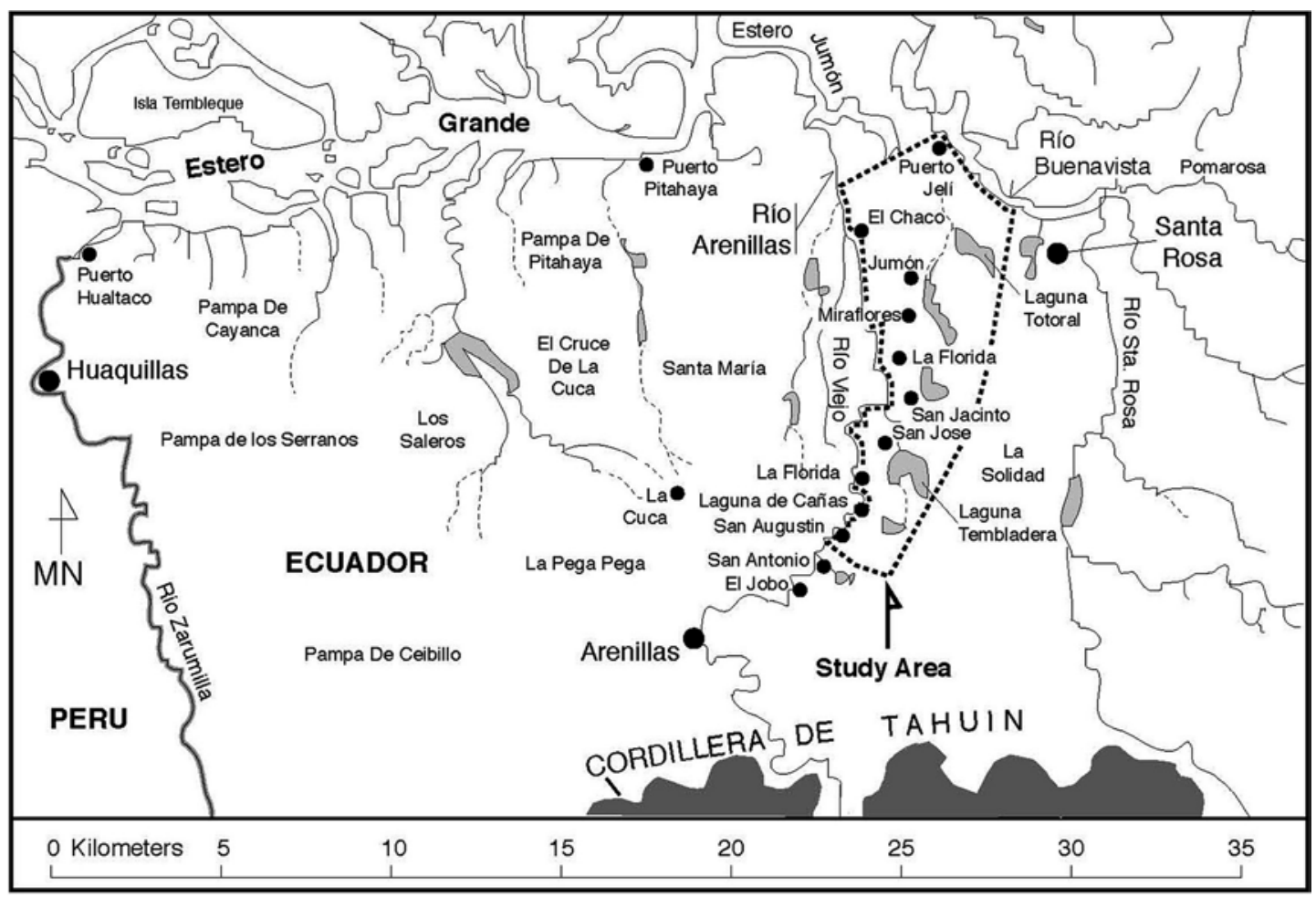

Figure 2. Southern coastal El Oro Province. Landscape features are indicated and regional names and study area are highlighted. Areas over 100 masl along the Cordillera de Tahuín are color indicated. 
annual variation is a function of diurnal changes in cloud cover and the retreat of the Peru Current, while the $8^{\circ} \mathrm{C}$ annual variation to the north reflect higher levels of precipitation, greater humidity, and solar radiation (Ferdon 1950:51-52, 55, 56, figure 24; Momsen 1968:96-98; Murray et al. 1975:345; Cane 1983) (Table 2).

\section{Environmental Setting: Coastal El Oro Province, Ecuador}

Southern coastal Ecuador is situated in the Straits of Jambelí along the southern portion of the Gulf of Guayaquil and represents a barrier island estuary. Meandering streams interlaced with fresh and salt-water lagoons and oxbow ponds, are dispersed throughout the landscape - habitats particularly sensitive to climatic perturbations. Southern coastal El Oro Province encompasses the area from the Jubones River, north of Machala, to the Peruvian border, an east to west distance of about $45 \mathrm{~km}$. The Cordillera de Tahuín is to the southwest and these foothills range between 100 to 200 masl and are distinct geologically from the Andes (Feininger 1980). The north/south transitional gradient represents a distance of about $65 \mathrm{~km}$ and ranges from wet subtropical forests in the Guayas Basin, Ecuador, to the extremely dry desert coast of northernmost Peru (Staller 1994, 2000). The estuary represents an ecotone, or transitional environmental zone and the local flora and fauna are characterized by a high incidence of endemism (Gentry 1977, 1986, 1988; Dobsen and Gentry 1991; Parker and Carr 1992). The region is renown in the biological sciences for its endemic orchid species (Orchidaceae spp.) as well as hummingbirds e.g., (Amazilia spp.) (Ridgely and Greenfield 2001:356-359). Unlike other regions of the Ecuadorian coast, coastal El Oro is ecologically distinct due to the close proximity of the Andes, which begin their ascent only $15 \mathrm{~km}$ from the active shoreline $^{2}$ (see Figure 1).

The dry tropical forests consist of xerophytic thorn brush, dense clusters of mesquite or trupillo (Prosopis pallida) trees and algarrobo (Hymenaea spp. L.), as well as various species of columnar cactus (Cereus spp.) (Acosta-Solis 1959, 1970). A tall ceibo (Ceiba trichistandra Bakh) tree at the north end of the site is the most prominent natural feature

2 These topographic conditions more closely approximate regions to the south, the Peruvian and Chilean coast.
(Staller 1994:plate 7). Local villagers related that ceibos represent natural landmarks because they can be seen from great distances - the last remnants of what was, up to about eighty years ago, a biologically diverse old-growth forest (Staller 1994:189, 199-201; Staller 2001b).

The area around La Emerenciana is referred to as "los algarrobos", after the dense stands of algarrobo (Prosopis spp. L.) trees along this portion of the Buenavista River (Staller 1994, 2010; Tykot and Staller 2002). La Emerenciana is named after a small port once located 200 meters to the northeast along the Buenavista River (Staller 1994). The port was abandoned in 1964-65 after tectonic uplift made the river too shallow, indicating that, like northernmost Peru, this area is affected by tectonic uplift and/or subsidence (Staller 1994).

The dry tropical forests consist of five primary environmental zones: 1) mangrove forests situated on the offshore islands and foreshore lagoons and beaches; 2) Fresh and saltwater marshes and swamps beside the primary river channels, ox-bow lagoons and seasonal ponds; 3 ) dry tropical forests on the coastal plain or savanna; 4) a banded salt flat, or saltiral, distinguished by a dramatic reduction or a complete absence of surface vegetation, forming a natural barrier between mangrove (mangal) plant communities and the dry tropical vegetation of the lowland savanna (pampas); and 5) piedmont forests concentrated in the higher elevations of the Tahuín Cordillera and foothills of the Andes (see Figure 2; Table 3). The floral and faunal ecology are seasonally varied, highly diverse and ecologically complex, thus extremely fragile and susceptible to the effects of El Niño induced climatic variation (Wolf 1892:Map II; Cañadas-Cruz 1983; Caviedes 1975, 1984; Chapman 1976, 1977; Carter 1988).

Environmental and climatic research on a series of glacial lake deposits from the nearby highland Cuenca Valley, Ecuador produced extraordinarily detailed data on long-term El Niño events, chronology, tectonic activity, environmental change and the Holocene climate (Rodbell et al. 1999, 2002; Vuille et al. 2000; Moy et al. 2002; Hansen et al. 2003; Andrus et al. 2008). These lake core and archaeological data provide independent lines of evidence from the surrounding highlands and regions to the south that document possible effects of ancient El Niño related phenomenon. They are also evidence of El Niño chronology that precisely correlates with the multiple lines of data presented here. 
Table 3. Distribution of Prehispanic sites by association to environmental zones in the regional settlement survey.

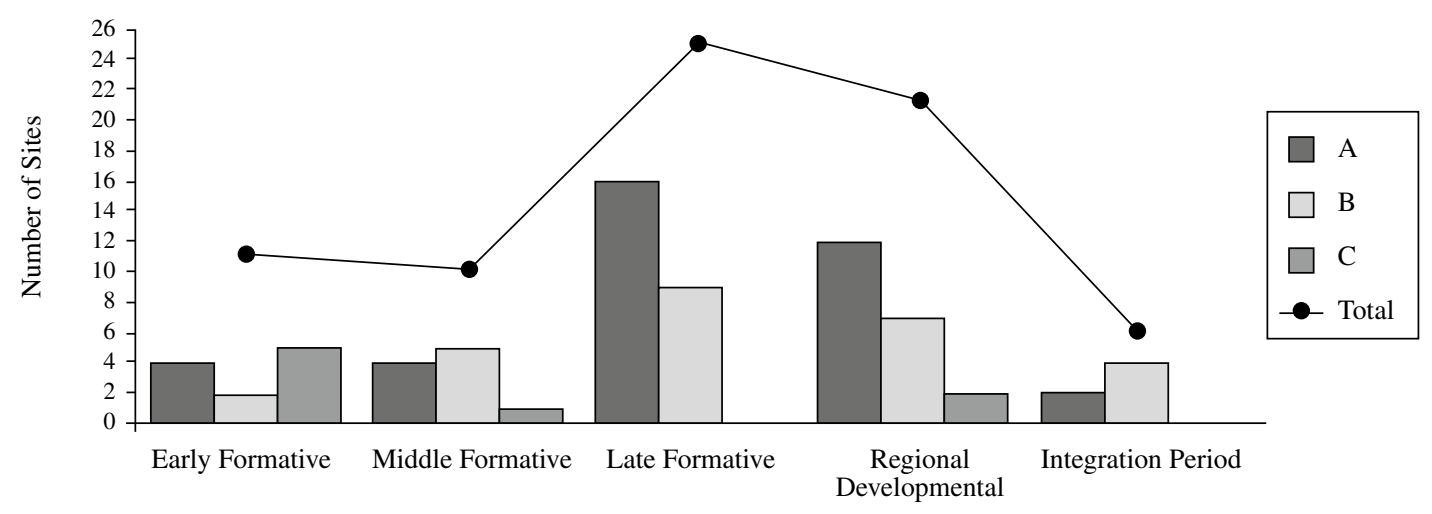

Key:

$\mathrm{A}=$ Sites located within the floodplain adjacent to wetland ponds and lagoons.

$\mathrm{B}=$ Sites located on the lowland savanna on knoll tops adjacent to wetland ponds and lagoons.

$\mathrm{C}=$ Sites located on the salt flats (saltiral) and fossil beach ridges adjacent to brackish ponds and the mangrove forest.

*Values are based upon cultural components from both single and multicomponent sites identified in regional settlement survey.

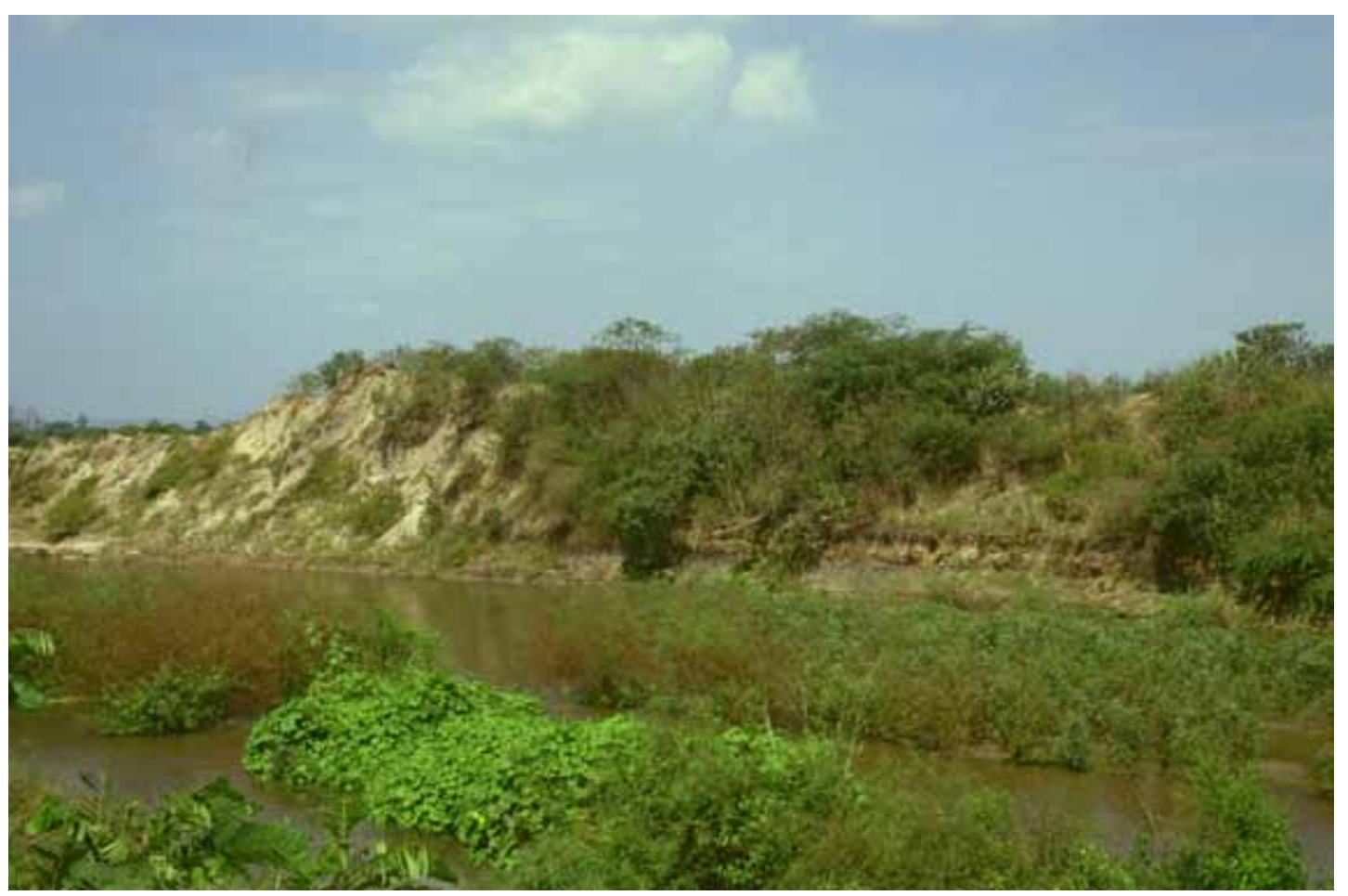

Figure 3. A vertical section of the fossil beach ridge associated with La Emerenciana as it appears along the recently modified Arenillas River channel. This beach ridge was clearly visible in regional survey and its cross section exposed after modification of the river channel by the Ecuadorian military as part of the Tahuín Dam Project (Facing SW). 
Three fossil beach ridges were identified in systematic regional survey (Staller 1994, 2000). These geological features record accretional history that over the millennia spread fine white sand throughout the lowland savanna (Figure 3). Beach ridges in some cases represent proxy records of prehistoric El Niños ${ }^{3}$ (Richardson 1983). Other lines of evidence include flood deposits, and archaeological middens and soils.

Large-scale excavations at the Valdivia ceremonial center of La Emerenciana indicate repeated site abandonment as do sites identified in regional settlement patterns (Staller 1994). Geological and historical data further indicate this is a tectonically active region (Gleaser 1978; Barazangi and Isacks 1979; Feininger 1980, 1982). Although seismic activity cannot be completely ruled out as a factor to site abandonment, more recent climatic data indicate El Niño must also be taken into account. Climatic evidence suggests an increase in the frequency and duration of El Niño related phenomena along the eastern Pacific after 5800 cal B.P. with the modern and historical range established $~ 3000$ cal B.P. (Sandweiss 2003; Sandweiss et al. 1996, 2001, 2007, 2009; Andrus et al. 2008). Such data appear to be important for our understanding of settlement patterning because during this time the region experienced an initial dramatic decline and subsequent increase in population density and site size during the Late Formative i.e., after c. 1000-800 B.C., involving a preference for alluvial soils and direct access to lowland lagoons and ponds (Staller 1994, 2000, 2010).

\section{Pre-Hispanic Settlement Patterns along the Lower Arenillas River}

Systematic settlement survey between the lower Arenillas and Buenavista River valleys recorded a total of fifty-two sites corresponding to the entire pre-Hispanic sequence and document the first evidence of Valdivia culture this far south along the coast (see Figure 4, Table 3). Survey methodology involved systematic $100 \%$ coverage of the terrain using both topographic maps and aerial photos obtained from the Ecuadorian military (see e.g., Willey 1953, 1962; Parsons 1974). Differences in

3 The beach ridge under La Emerenciana is the furthest inland, thus the earliest of such geomorphological features (Staller 1994).

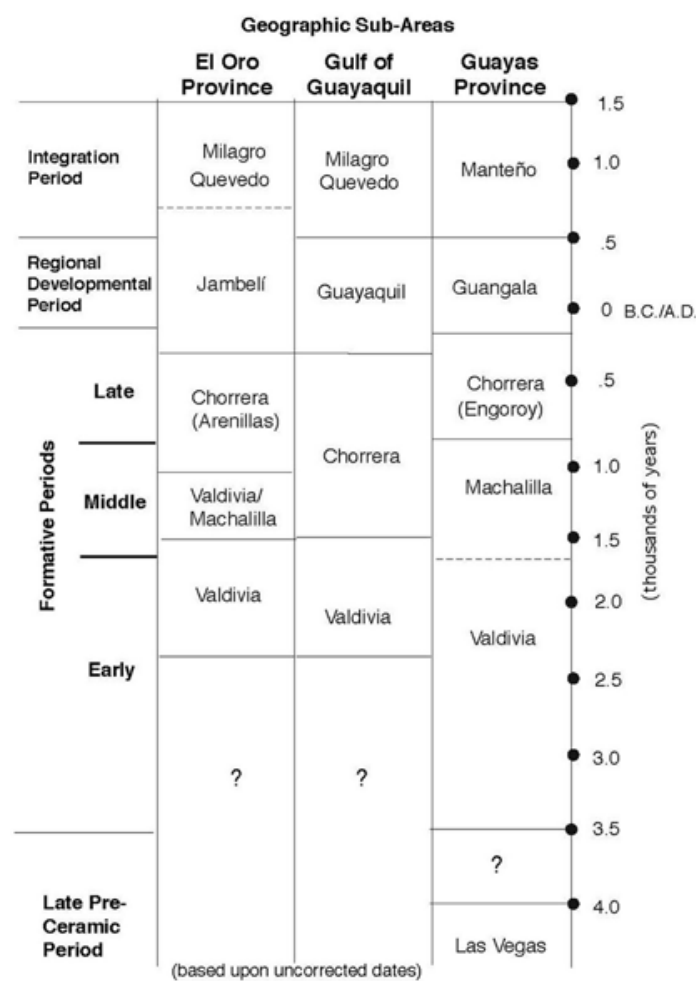

Figure 4. Cultural chronology of southern and southwestern coastal Ecuador.

settlement patterning have also been reported as indicators of climate and changes in human adaptation. Eleven late Valdivia sites were identified in two distinct patterns, along the most inland fossil beach ridge, and on knoll tops beside stream channels. Valdivia ceremonial centers apparent by the presence of two artificial earthen mounds were La Emerenciana and Jumón (Staller 1994, 2000). An earthen mound at La Emerenciana revealed four upright fully articulated bundle burials and one upright bundle burial was uncovered from one of the two earthen mounds at Jumón ${ }^{4}$ (Staller 1994,

$4 \quad$ Burials at La Emerenciana included four adult females fully articulated bundle burials all associated with the stratum 5 floor 2 occupation and a sub-adult fully articulated associated with the final occupation of the site pertaining to stratum 6 (Staller 1994; Tykot and Staller 2002; Ubelaker and Jones 2002). The burial at the earthen mound in Jumón was also tightly flexed adult female (Staller 1994). These data are consistent with research at earthen mound at other Valdivia ceremonial centers such as Real Alto, Loma Alta, and San Isidro, supporting the prevailing assertion that they were first and foremost burial mounds (Lathrap et al. 1977; Norton 1982; Marcos 1988; Ziedler 1988; Staller 2001a). 
2000, 2001a, 2001b). Middle Formative settlements had significant reductions in occupation density and site size, and clustered on knoll top locations beside stream channels with ready access to coastal lagoons, seasonal ponds, and alluvial soils. Late Formative sites were absent along the innermost beach ridge. It is precisely at the beginning of the Late Formative (3000 cal B.P.) that modern and historic El Niño frequency patterns are established.

Valdivia localities are situated along the foreshore and near-shore estuary, as well as riverine localities (Staller 2001a). Coastal sites listed under category "C", are absent after the Early Formative and reappear during post-formative times - a period of over a millennium (Table 3). Increases in Late Formative settlements with high densities of occupation debris reflect a clear preference for knoll top localities beside stream channels with direct access coastal ponds and lagoons as well as terrestrial habitats and alluvial soils (Figure 5). A preference for riverine settings reflects a greater dependence upon domesticated plants and terrestrial animals and birds. The significant increase in site number and size during the Late Formative continues into the subsequent periods (Staller 2010:figures 4.22a-b). Such patterning suggests a corresponding shift in adaptation, possibly initiated by a greater overall frequency of El Niño.
Extensive lamination in Laguna Chorrera lake core deposits dated to between 3300 to $2600 \mathrm{cal}$. B.P. provide corroborating evidence of increased El Niño activity (Rodbell et al. 1999:figure 3; Moy et al. 2002:figure 1a-c). Increased El Niño frequency may explain the dramatic reduction in pre-Hispanic occupation during the Middle Formative, and why solely early diagnostics were identified, as well as the total abandonment of the foreshore between $\mathrm{c}$. 1450-500 B.C. The destruction and/or burial of the barrier reef may have been related to such reoccurring El Niño related activity or to the Mega event associated with site abandonment in stratum 5 and provide a basis for understanding the extinction of oyster for over millennia. Oysters reappear in abundance during the Regional Developmental and Integration Period (see Figure 4, Table 3). Jambelí Phase occupations with deep occupation horizons and middens reappear in the foreshore. Shell middens dispersed throughout the Pampas de Cayanca near Huaquillas stand over 13 to 16 meters high and 150 to 200 meters at the base (Staller 1994:plate 1).

Aridity and climatic instability provided the greatest challenges to adaptation in southern coastal El Oro. Archaeological and stratigraphic evidence from settlement survey and excavation indicates the ancient economy was mixed and diversified, and included hunting, plant gathering,

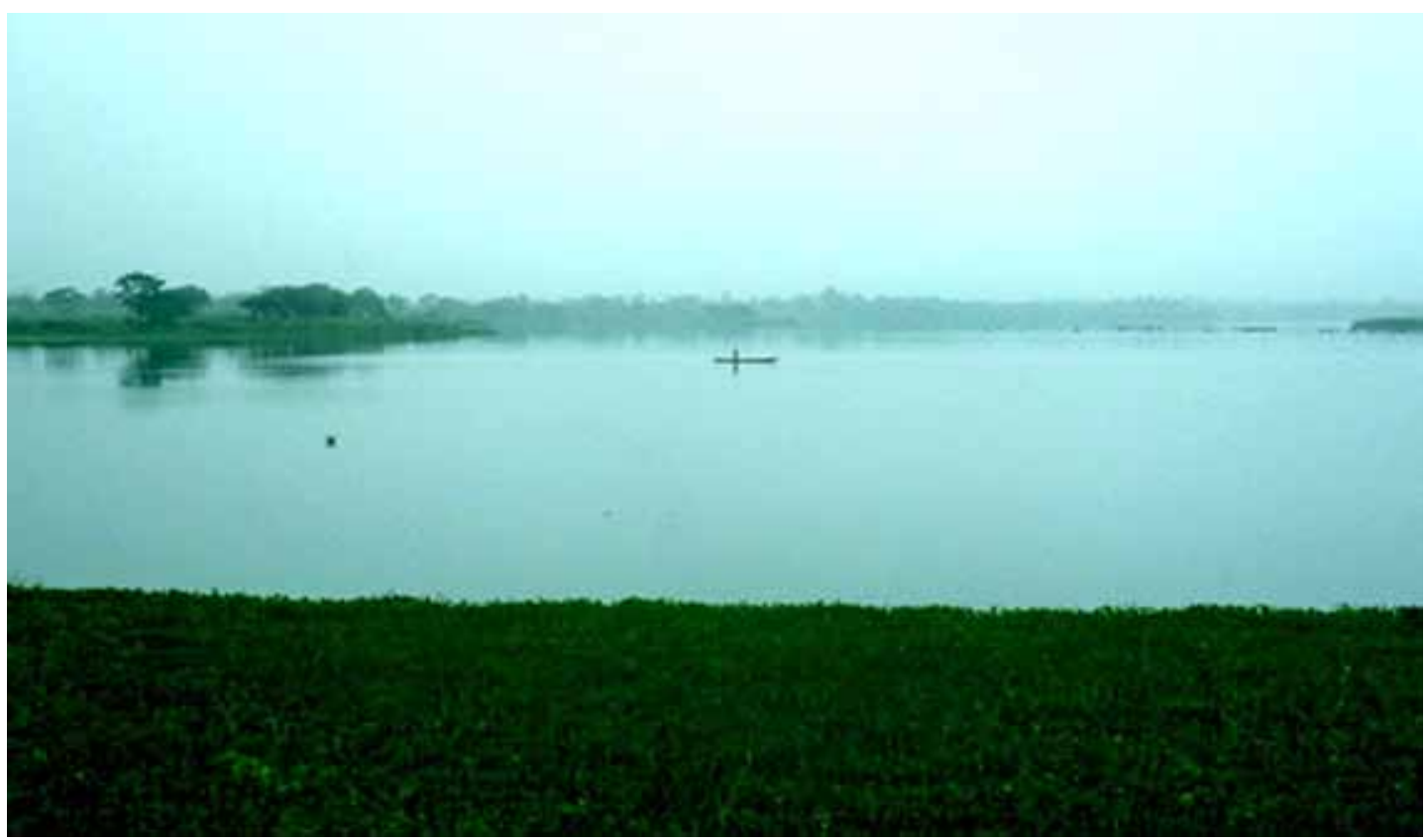

Figure 5. Fisherman casting a net on the Laguna de Tembladera during the dry season. The heavy fog reflects the garua that normally permeates this region of the coast from early April until late December (Facing North). 
agriculture, and aquatic resource exploitation as primary components (Staller 1994, 2000, 2001a, $2001 b, 2010)$. Stable isotope signatures from the $\mathrm{La}$ Emerenciana skeletons indicate aquatic resources formed a major portion of the diet and, although maize was consumed, it played a minor role in the subsistence diet and primarily consumed as beer or chicha (Tykot and Staller 2002:tables 5-6; see also Lathrap et al. 1977). There is some reason to suspect that the climatic and environmental changes induced by El Niño, may have played a central role in fostering a greater dependence upon agriculture, although the overall response to variations in resource availability generally favored flexibility or increased diet breadth over specialization.

\section{Pre-Hispanic Occupations at La Emerenciana}

The Valdivia ceremonial center La Emerenciana covers some 12.72-hectares making it one of the largest Early Formative in coastal Ecuador (Lathrap et al. 1977; Norton 1982; Marcos 1988; Staller 2001a). It is situated on a fossil beach ridge at 2.5 masl about $3 \mathrm{~km}$ from the present shoreline (Staller 2001 b:figure 7, 2003). Primary occupation spanned 700 to 650 years and corresponds to the final portion of the Early Formative Period c. 2200-1450 B.C. The Jelí Phase ceramic complex associated with Valdivia sites in this region is distinguished by the earliest directly and indirectly dated pedestal bowls, stirrup-spouts and single spout bottles, as well as, the earliest red on white banded pottery in the Andes (Staller 1994:356-400, 2001b:figures 22-29). Various archaeologists have suggested the red on white-banded tradition in southern highland Ecuador and the northern highlands of Peru is representative of the earliest pottery cultures in this part of the Andean highlands and representative of a cultural horizon called Chaullabamba (Uhle 1920a-b, 1922a, 1928, 1929, 1938; Staller 2007; Collier and Murra 1943; Hocquenghem 1991; Hocquenghem et al. 1993; Moore et al. 2008). These regions of the Andean sierra relate to non-Quechua and Aymara speaking cultures involved in the early spread of ceramic technology, maize (Zea mays L.), Strombus galeatus conch and Spondylus spp. oyster shell to the adjacent highlands and south along the coast (Collier and Murra 1943; Paulsen 1974; Hocquenghem et al. 1993; Staller 2007). Initial appearance of red on white-banded diagnostics in coastal El Oro Province dates to as early as 2200 B.C., this based upon both AMS and conventional dates (Staller 2001b, 2007; Staller and Thompson 2002; Tykot and Staller 2002). Initial site abandonment and burial by a fossil beach ridge may relate to a Mega-El Niño dated to 2150 B.C. consistent with similar dates in regions of the Andes (see Rodbell et al. 1999:figure 3; Dillehay and Kolata 2004:table 1). Reoccupation and fossil beach ridge formation is ${ }^{14} \mathrm{C}$ dated to between c. $2200-1450 \mathrm{cal}$ B.C. Another abandonment is followed by a brief final reoccupation dated to c. 1450 B.C. (Table 4). Geographic and cultural definitions of the various archaeological subregions have been previously

Table 4. La emerenciana radiocarbon chronology

\begin{tabular}{lcc}
\hline \multicolumn{1}{c}{${ }^{14}$ C Laboratory No. } & $1{ }^{14}$ C B.P./ & $\begin{array}{c}\text { Calib.4.1.2 } \\
1-\delta \text { age range B.C. }\end{array}$ \\
\hline a) SMU-2241 & 3361 B.P. \pm 246 years & $1935-1323$ cal. B.C. \\
b) SMU-2226 & 3400 B.P. \pm 220 years & $1941-1428$ cal. B.C. \\
c) Beta-125106 & 3720 B.P. \pm 40 years/ & $2137-1979$ cal. B.C. \\
d) SMU-2225 & 3700 B.P. \pm 40 years & \\
e) Beta-125107 & 3707 B.P. \pm 148 years & $2288-2245$ cal. B.C. \\
f) SMU-2563 & 3810 B.P. \pm 50 years/ & $2240-2201$ cal. B.C. \\
\hline
\end{tabular}

Note: All material dated is charcoal. BETA dates are AMS corrected for ${ }^{13} \mathrm{C} /{ }^{14} \mathrm{C}$ fractionation. SMU dates are standard assays. All dates are calibrated using Calib 4.1.2 (Stuiver et al., 1998), with a minus 24-year Southern Hemisphere atmospheric sample adjustment and are reported here as a one-sigma range. Staller (1994:393-396, Figure 5) provides the contextual information on the SMU dates. Staller and Thompson (2002:45, Table 10) provide contextual information on the Beta dates. All are from Stratum 5 except SMU-2241, which is from Stratum 6. 


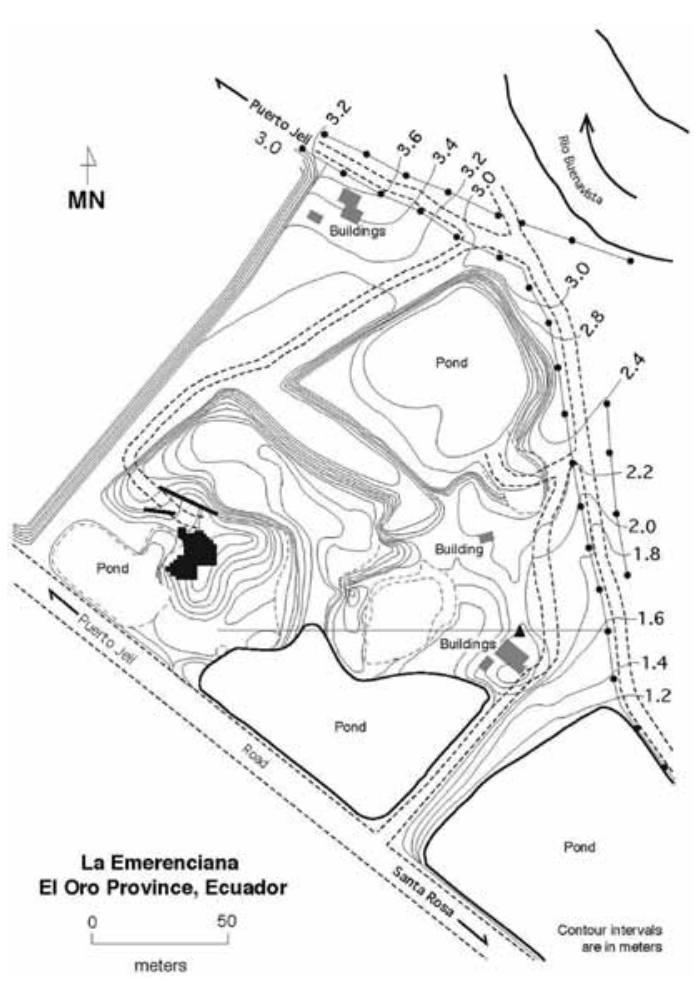

Figure 6a. The ceremonial center of La Emerenciana is situated on a fossil beach ridge, one of three such topographic features identified in regional survey in the salitral or salt flats. Two earthen mounds were identified and the larger NW mound was the focus of the excavation. Another earthen mound was identified under a modern habitation just south of the site datum. Parts of the surrounding coast were modified by shrimp pond construction.

discussed in detail (see Staller 2001a:197-201, figure 2).

\section{Excavations at the ceremonial center of La Emerenciana}

La Emerenciana is situated with direct access to maritime and estuarine resources, as well as riverine soils, and is the largest site with earthen mounds identified in regional survey for any time period. Excavations were restricted to the summit of the northwest platform, one of two earthen mounds at the site (Figure 6a). The earthen mound is oval in shape 2.5 meters high, and measures 200 meters $(\mathrm{N}-\mathrm{S})$ by 150 meters (E-W) with two oval clay platforms on the summit ${ }^{5}$ (Staller 1994:209). Four

$5 \quad$ The north platform measures $5(\mathrm{~N}-\mathrm{S})$ by $4(\mathrm{E}-\mathrm{W})$ meters, while the southeast platform measures $3.5(\mathrm{~N}-\mathrm{S})$ by $2(\mathrm{E}-\mathrm{W})$

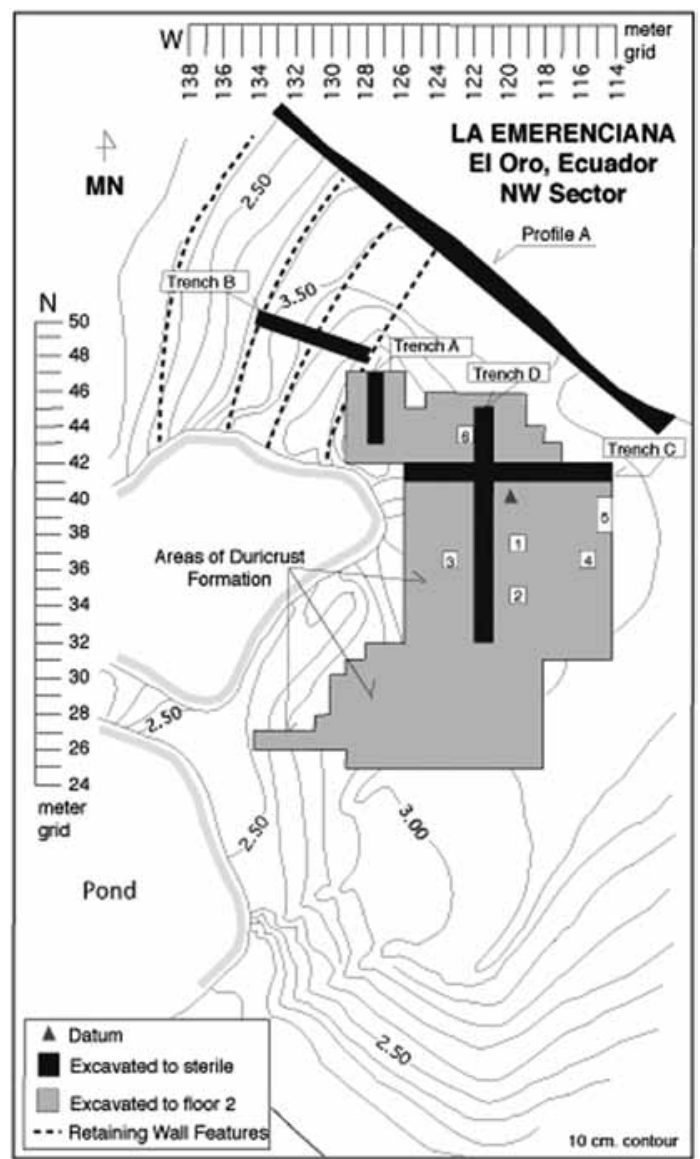

Figure 6b. Excavations on the NW platform mound showing designated Trenches A-D and Cuts 1-6 dug to sterile levels, and units dug to the surface of floor 2 .

trenches (A-D) were dug to sterile levels, and $332 \mathrm{~m}^{2}$ of a buried prehistoric occupation surface (floor 2) were exposed. Five-meter square units (Cuts 1 to 4 , 6), and a 1 by 2 meter pit (Cut 5) were excavated to sterile to record more specific data on stratigraphic variation (Figure 6b). A twenty-nine meter long vertical section (Profile A) was cleared in order to provide continuous stratigraphic information on this portion of the mound ${ }^{6}$ (Staller 2001b:Figure 13).

meters, and is $15 \mathrm{~cm}$ thick (Staller 1994; Tykot and Staller 2002). These clay platforms (baharreque) are held together with cane branches that were tied together with cord. Their impressions were still visible when they were exposed from the overlying sediments (Staller 1994).

6 The excavations at La Emerenciana were carried out in part because the site was partially destroyed by artificial ponds constructed on the western parts of the site by local shrimp farmers. The primary reason that the site was still partially intact was because the ponds would not hold water because 


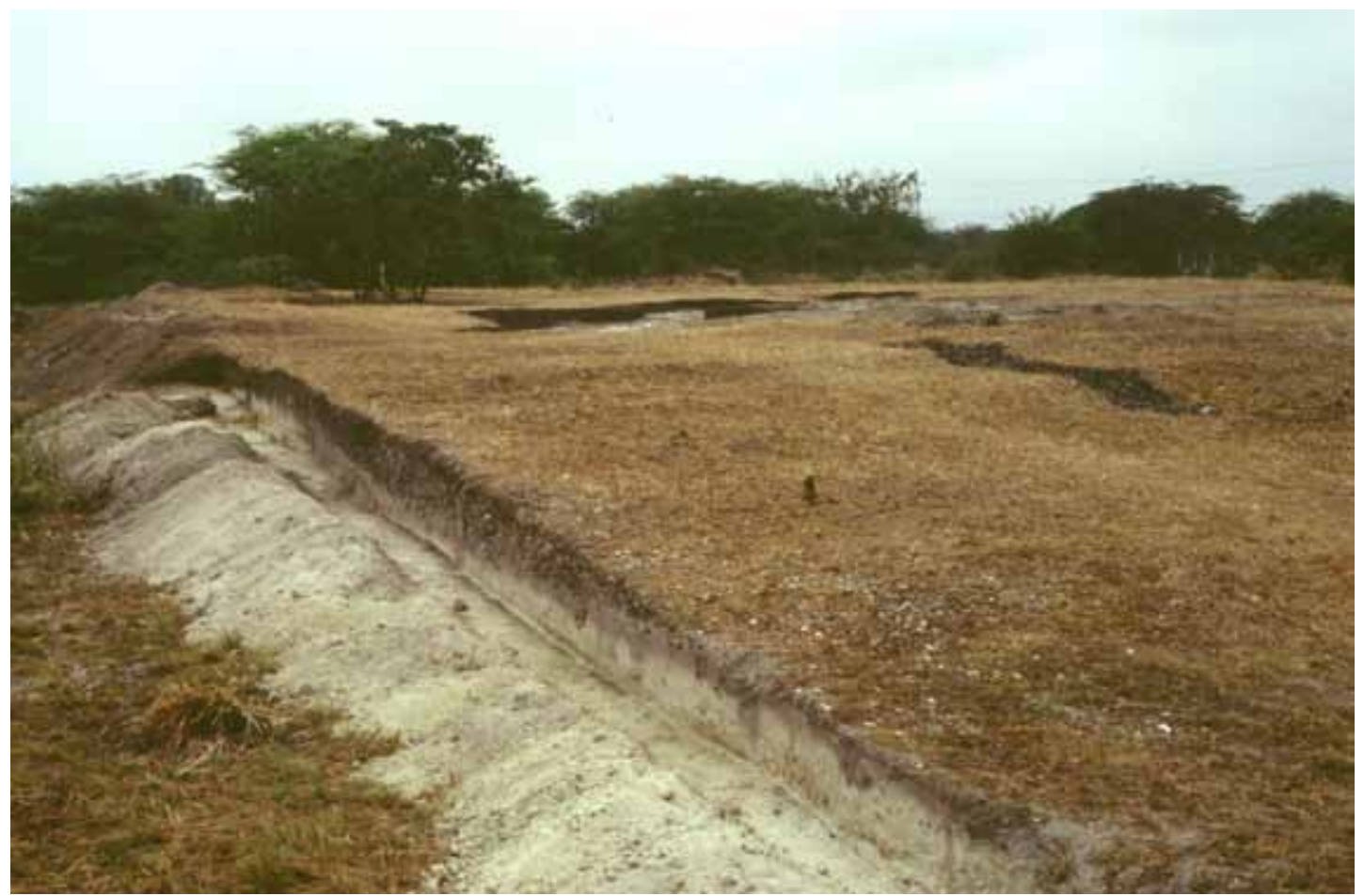

Figure 7. Profile A in cross section immediately after exposing the sediments. Trench B is in the forefront. Artificial step or terrace features were initially identified in the Trench B excavations and verified in Profile A (Facing SW).

Profile A and the Trench D excavations uncovered three descending retaining walls or stepped terraces in the west and northern parts of the earthen mound, and these modifications were verified in the Trench B excavation (Figures 6a, 7).

Excavations were primarily by natural stratigraphic layers and uncovered one hundred and thirty nine features, primarily consisting of architectural modifications associated with artificial mound construction, burials, four fully articulated upright tightly flexed burials, and various ritual offerings (Staller 1994, 2010; Staller and Thompson 2002:figure 7; Ubelaker and Jones 2002). Initial occupation is associated with stratum 3 and dated to ca. 2400 B.C., followed by beach ridge formation (stratum 4). Later occupations date to between 2000-1450 B.C. and are associated with stratum 5 and a brief reoccupation associated with stratum 6 (Figure 8, Table 4). Lithic debris was limited to only 20 artifacts, but included exotics; two obsidian flakes sourced to different outcrops in the Valley of Quito that represent the earliest dated obsidian in coastal Ecuador (Staller

of the fine white sand on which the site stands (Staller 1994, 2001).
1994; Asaro et al. 1994). Most artifacts consisted of sherds, and clear evidence of ceramic production $^{7}$ (Staller 1994). Offerings consisting of ocher covered pebbles and a few chipped quartz flakes and some polishing stones ${ }^{8}$ (Staller 1994).

Differences in the color, texture and composition of the various strata allowed identification of the stratigraphic units and they were classified on the basis of grain size analysis (Tables 5a-b). Layered sequences of stratigraphic units were divided according to their artifact content. All trenches and units were excavated following the conformities and contours of the natural stratigraphic layers, and differentiated by the physical properties of the strata.

7 Ceramic manufacturing at the site was documented by a semi-subterranean kiln with waster sherds at its base identified in cross section in the southern portion of the site (Staller 1994).

8 Ocher covered pebbles and stones are commonly left as offerings at later Andean sites in both the highlands and coast, but have their earliest appearance at this and other Valdivia ceremonial centers. There was no evidence of domestic habitations in contrast to other Valdivia ceremonial centers such as Real Alta and Loma Alta (Marcos et al. 1976; Lathrap et al. 1977). 
Idealized profiles of stratigraphic layers at La Emerenciana (OOSrSr-42)

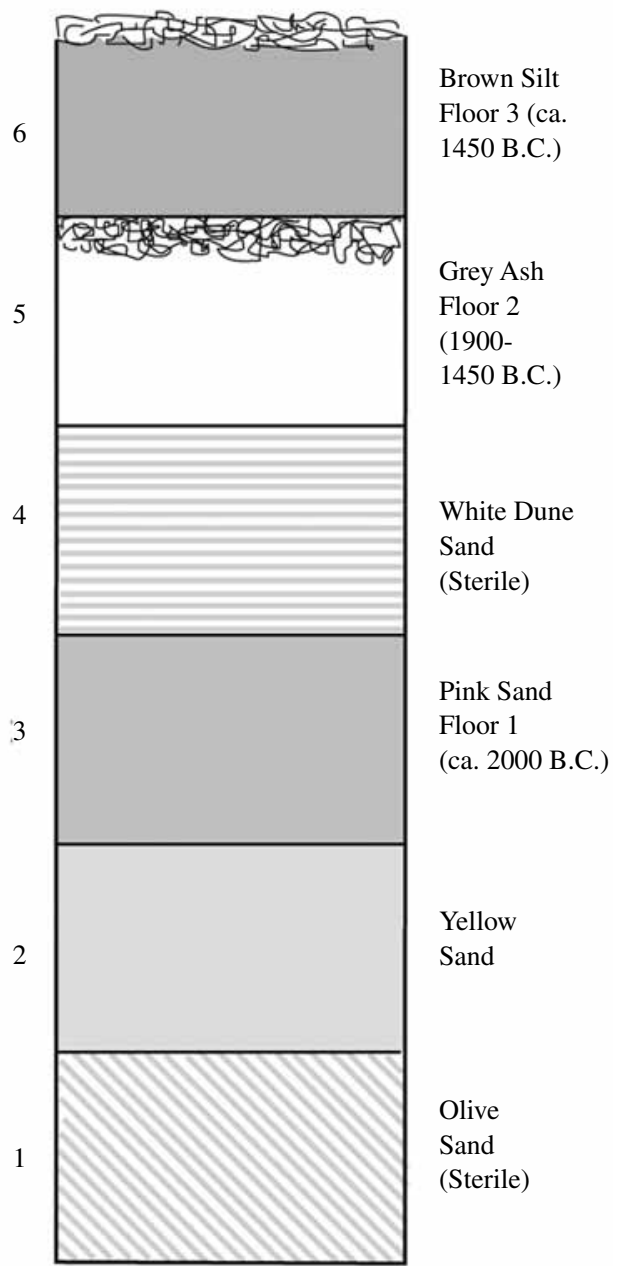

Figure 8. Idealized profile of the various stratigraphic layers 6-1 identified in excavations.

Artifacts established the stratigraphic sequence and permitted the recognition of reversed stratigraphy, as well as primary and secondary deposits (Joukowsky 1980:152; Stein 1990:516).

A concentration of marine shell extending over $40 \mathrm{~cm}$ in cross section was identified on the northern portion or seaward portion of the site in Trenches A, B, and northern portion of Profile A. Arbitrary increments of $20 \mathrm{~cm}$ were used, since the smallest natural unit of analysis (i.e., shell layer) was too large to detect subtle changes in the vertical distribution. On the summit of the earthen mound the shell layer has a maximum depth of only 5 to
$10 \mathrm{~cm}$ over the surface to floor 2, and was absent on the southeastern portion of the mound in the Cut 4 and 5 (Figure 9). The homogeneous grey ashy loam (stratum 5, living floor 2) has been identified at Valdivia sites throughout coastal Ecuador (e.g. Meggers et al. 1965; Estrada et al. 1964; Lathrap et al. 1977; Marcos 1988) and also at later Jambelí Phase sites (Staller 1994; see also Currie 1985). Archaeologists proposed explanations for such soils, although geological or geomorphological evidence has been lacking. The surface of stratum 5 designated as living floor 2 , represents a buried occupation surface (see Figure 9). Highest concentrations of cultural remains, primarily sherds and ancient shells, were in the uppermost $10 \mathrm{~cm}$-apparently because the interface formed on a stable soil surface (Staller 1994).

\section{Natural Stratigraphy at La Emerenciana}

The A-Bw/Btn-Bk horizon sequence of soils is characteristic of well-drained semi-arid conditions (Table 6). The five lower strata were continuous across the site, and two stratigraphic layers (3 and 5) contained prehistoric artifacts pertaining to Valdivia culture. Stratum 6 was restricted to the northwest sector and associated with the final abandonment (Staller 2001a:table II). The following geomorphological, archaeological and shellfish counts are presented to test the hypothesis that repeated site abandonment and widespread geomorphological changes were induced by ancient El Niño events (Staller 1994:144-153).

The lowest layer, stratum 1 is olive beach sand with nodules of decomposing organic and gravel inclusions identified at $97 \mathrm{~cm}$ below datum (Figures 10-12). Inspection of a vertical section along the stream channel measuring $20 \mathrm{~m}$ long and $5 \mathrm{~m}$ deep suggests this layer reaches to at least three meters, with gravel lenses and shell lag deposits, remnants of foreshore deposits of fluvial origin throughout. Cross-bedding was noted below $2.5 \mathrm{~m}$, the result of fluvial processes - post-depositional weathering through the movement of groundwater, leaching and dissolution of carbonates altered the chemistry of the sediment (Woods 1977:249). Various shell lag deposits and gravel lenses indicate groundwater movement, evapotranspiration or hydrological and sea level changes over geological time (see Figure 12). The gravel lenses and clay shell lag deposits effect retention of organic matter, 
Table 5a. Grain size analysis (Hydrometer).

\begin{tabular}{lccccc}
\hline \multicolumn{1}{c}{ STRATUM } & WEIGHT $(\mathrm{g})$ & GRAVEL $(\%)$ & SAND $(\%)$ & SILT $(\%)$ & CLAY $(\%)$ \\
\hline 6 & 50.00 & 0 & 88 & 8 & 4 \\
6-5 interface & 40.84 & $<0.5$ & 90 & 7 & 2 \\
$5-4$ interface & 36.08 & $<0.5$ & 83 & 11 & 6 \\
4 & 50.00 & 0 & 90 & 4 & 6 \\
3a (calcrete) & 56.13 & 0 & 96 & 2 & 2 \\
2 & 50.00 & 0 & 92 & 8 & 0 \\
1 & 50.00 & 0 & 92 & 2 & 4 \\
1d (shell lag) & 50.00 & 0 & 94 & & \\
\hline
\end{tabular}

Table 5b. Grain size analysis (Pipette)

\begin{tabular}{lccccc}
\hline \multicolumn{1}{c}{ STRATUM } & WEIGHT $(\mathrm{g})$ & $\begin{array}{c}\text { SAND } \\
\text { WEIGHT }(\mathrm{g})\end{array}$ & SAND $(\%)$ & SILT (\%) & CLAY (\%) \\
\hline $5 \mathrm{~b}$ & 27.14 & $23.73(3.34)$ & 87 & 6 & 6 \\
5 & 22.92 & $19.15(3.67)$ & 84 & 7 & 9 \\
1a shell lag & 36.32 & $30.45(5.73)$ & 84 & 7 & 10 \\
\hline
\end{tabular}

Note: Weight ( $\mathrm{g}$ ) refers to corrected total weight. Residuals or dry weight is given in parentheses beside the sand weight and is also in grams. Analysis and interpretation was carried out by the department of geography at the University of Wisconsin-Milwaukee.

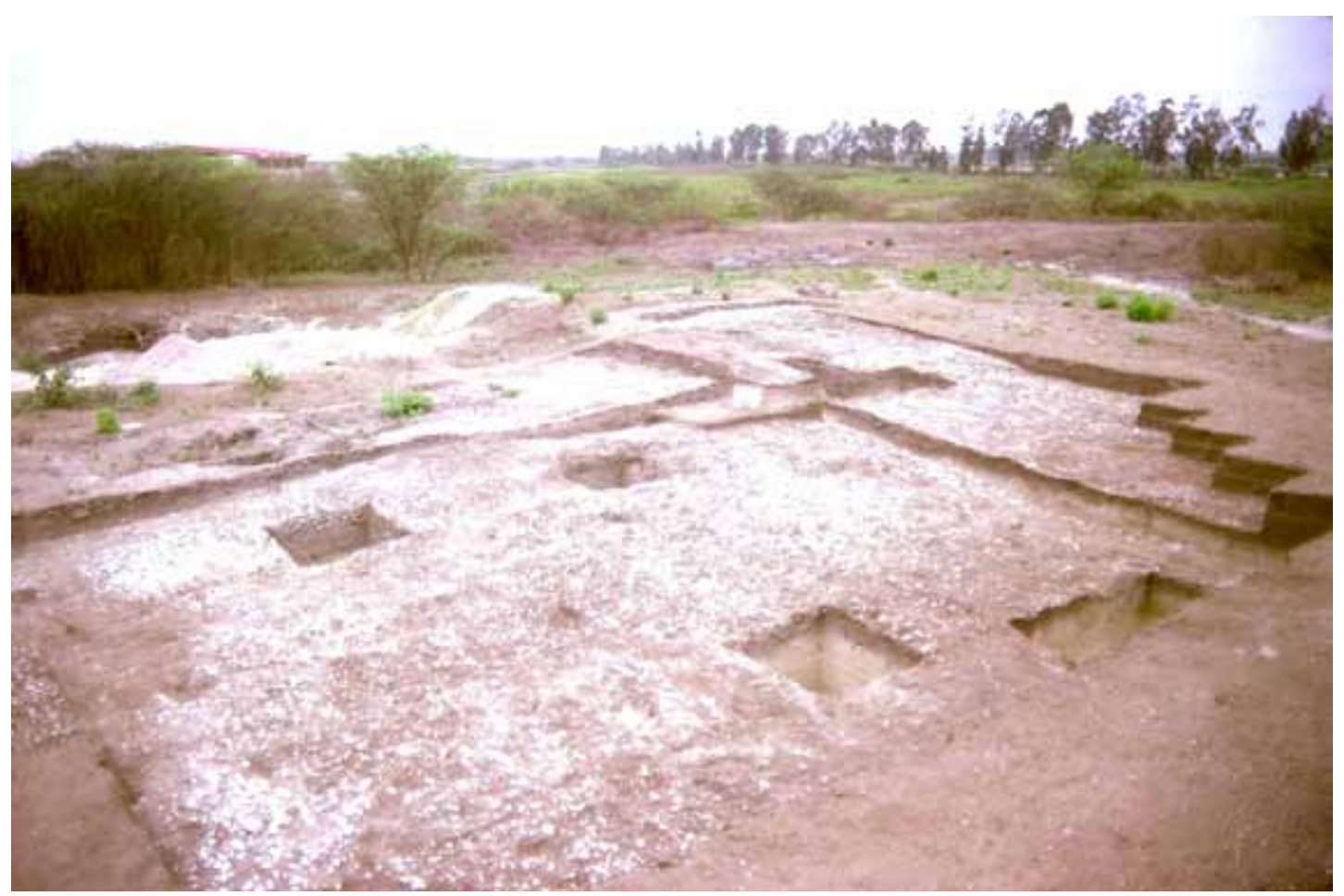

Figure 9. Floor 2 excavations showing units, trenches and exposure of the paleosol. Note the depth of Stratum 6 in the western part of the excavated area (Facing North). 


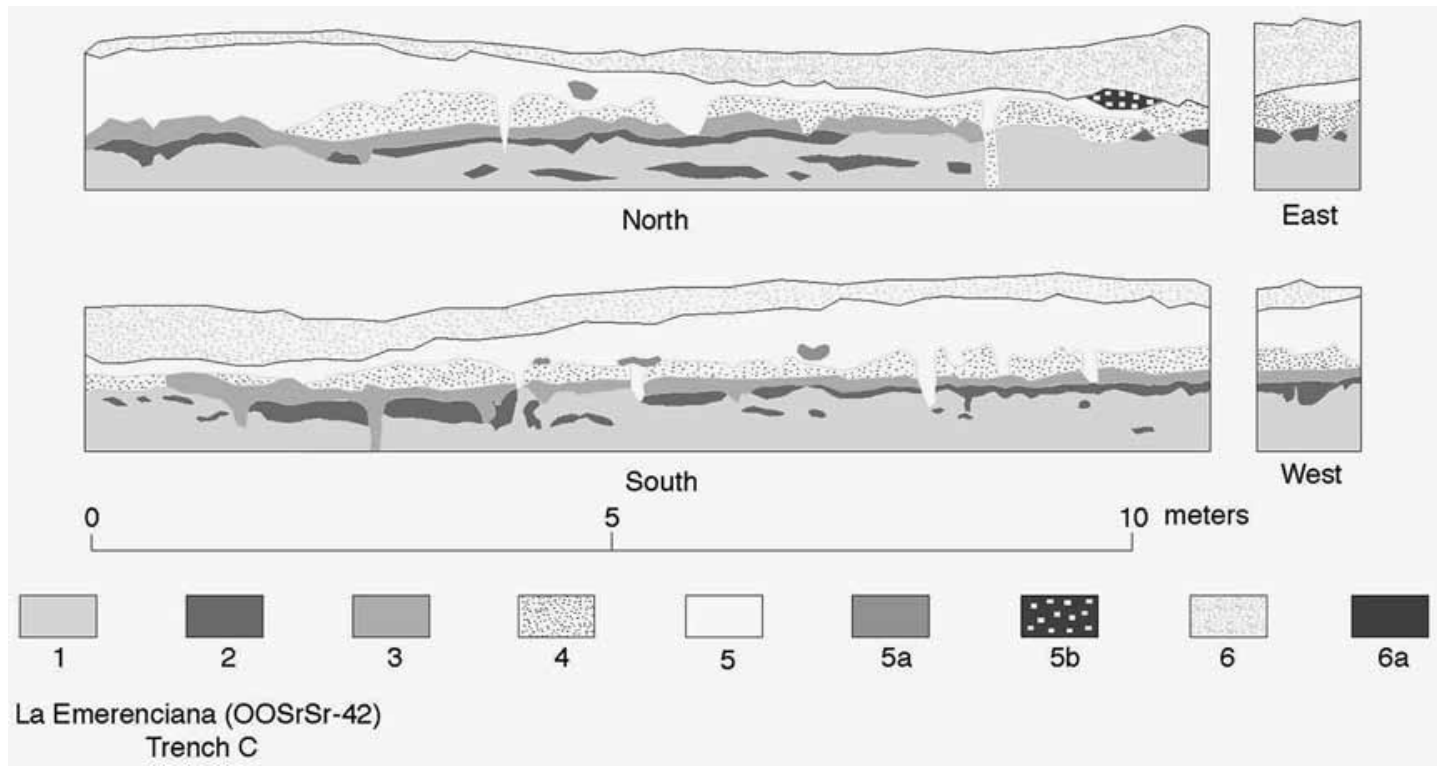

Figure 10. Vertical section of Trench C showing the stratigraphic layers. See Table 3 for key to stratigraphic layers and sublayers.

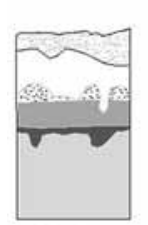

North

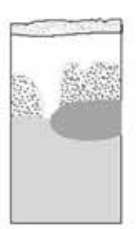

South

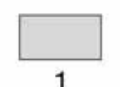

1

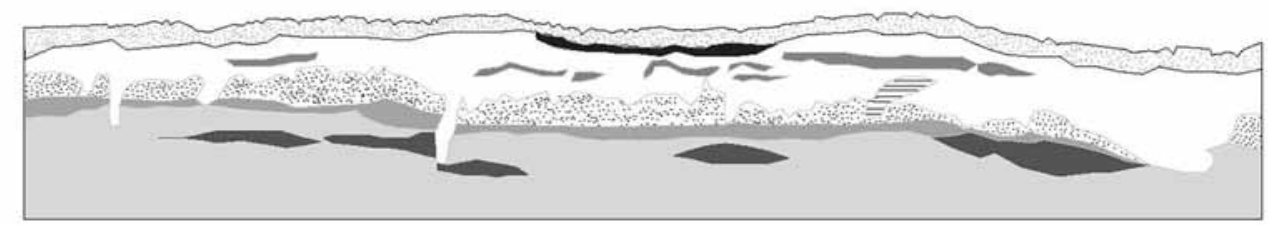

East

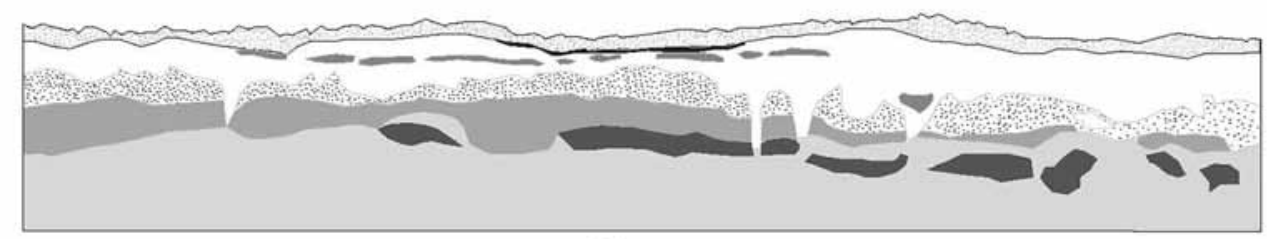

0

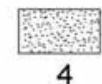

10 meters

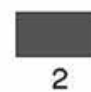

3
5
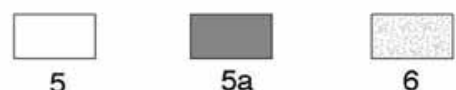

\section{West}

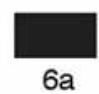

\section{La Emerenciana (OOSrSr-42)} Trench D

Figure 11. Vertical section of Trench D showing the various stratigraphic layers. See Table 3 for key to stratigraphic layers and sublayers.

explaining in part the preservation of faunal remains (Staller 1994). Macrobotanical remains were not preserved in any of the sediments, however plant microfossils were recovered from carbon residues in pottery sherds (Staller and Thompson 2000, 2002; Tykot and Staller 2002).
Stratum 2 is yellow sand the result of postdepositional weathering associated with groundwater movement (see Table 6). The deposition and decomposition of organic and inorganic compounds left concentrations of calcium compounds, carbon, phosphorous, and trace metals that apparently created 


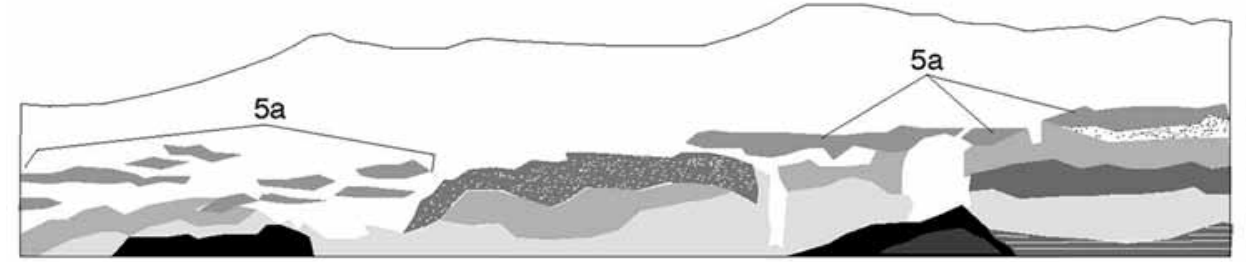

North

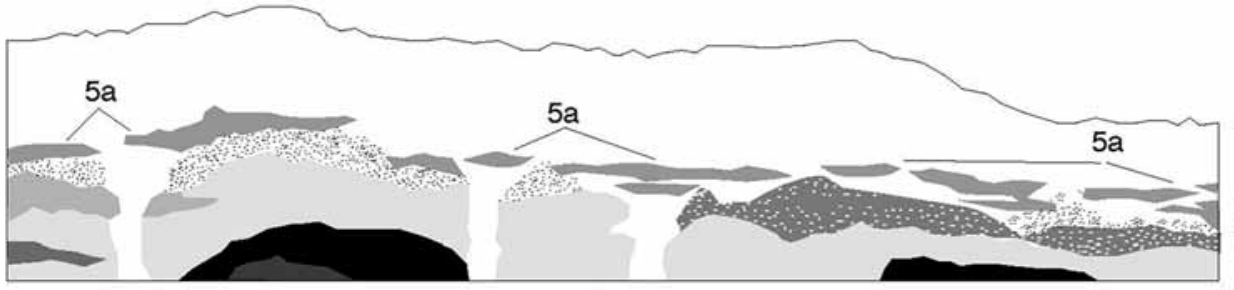

South

0
5 meters

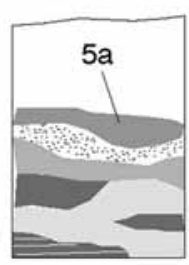

East

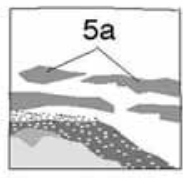

West

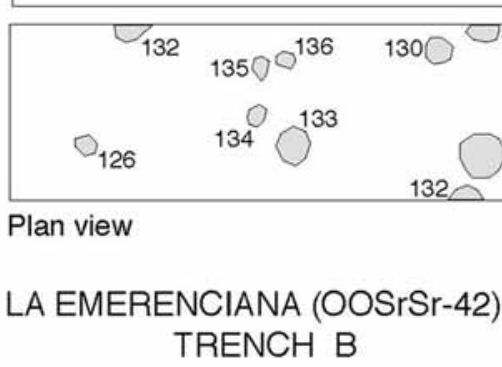

TRENCH B
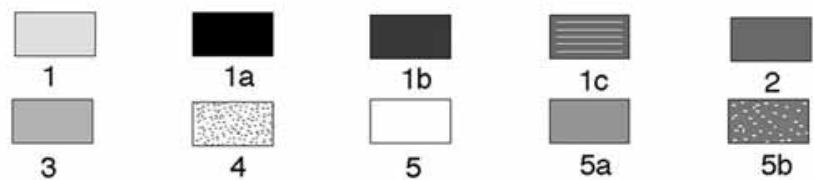

Figure 12. Vertical section and plan view of Trench B showing the various stratigraphic layers. Features are architectural, posts molds associated with the construction of retaining walls. See Table 3 for key to description of layers and sublayers.

chemical changes in the soil. Geological studies indicate this coloration may also be produced by the movement of iron oxides via water percolating through shell lag deposits (Woods 1977:298).

Stratum 3 is pink sand extending between approximately 94 and $124 \mathrm{~cm}$ below datum, containing archaeological features including pits, numerous post molds, and portions of foundations of habitation structures, indicating this was a prehistoric occupation surface designated living floor 1 (see Figures 10-11). Ceramic diagnostics correspond to the middle of the sequence and, despite the various features, there was a relative paucity of marine shells or artifacts, and a total absence of organic and faunal remains - probably related to leaching and post-depositional alterations in the lower layers. Leaching of phosphates and iron oxides from stratigraphic layers 5 and 3 was evidenced in the underlying layer and calcrete deposits by a yellow to light brown coloration (see Table 6). The abundant faunal remains found with various features in stratum 5 were not preserved in this layer.

Stratum 4 is a sterile layer made up of fine white quartzitic dune sand with calcium carbonate inclusions. Some blending was noted with the overlying grey ashy loam and part of a fossil beach ridge extending to the Peruvian border and beyond (see Figure 3). Lake core deposits in the Andes Cordillera directly northeast provide indirect lines of evidence to strengthen the stratigraphic interpretation for repeated site abandonment. Beach ridge formation is often a result of El Niño related phenomena and may correspond to a Mega-El Niño recorded in the Laguna Pallcacocha lake cores ${ }^{14} \mathrm{C}$ dated to 4040 B.P. (Rodbell et al. 1999:81, figure 3; Moy et al. 2002:figure 1a-c). This chronology roughly coincides with an El Niño dated to ca. 2150 B.C. recorded at several sites in the Jequetepeque River valley to the south (Dillehay and Kolata 2004:4326, table 1). Beach ridge formation is 
Table 6. Stratigraphic layers at La Emerenciana

\begin{tabular}{|c|c|c|c|c|}
\hline Stratum & Depth & Horizon & Color & Description \\
\hline \multirow[t]{2}{*}{6} & \multirow[t]{2}{*}{$0-55 \mathrm{~cm}$} & \multirow[t]{2}{*}{ A } & 10YR 5/3 & \multirow{2}{*}{$\begin{array}{l}\text { Brown fine silty loam, loosely consolidated in the upper } \\
\text { levels, denser in lower levels, with evidence of bioturbation } \\
\text { (fluvial deposit). }\end{array}$} \\
\hline & & & $-10 Y R 5 / 4$ & \\
\hline \multirow[t]{2}{*}{5} & \multirow[t]{2}{*}{$15-93 \mathrm{~cm}$} & \multirow[t]{2}{*}{ B } & 10YR 6/1 & \multirow{2}{*}{$\begin{array}{l}\text { Homogeneous grey ashy loam, loosely packed, very fine } \\
\text { texture, fine quartz inclusions with the consistency of talc, } \\
\text { and artifact and shell remains in the upper-most levels of the } \\
\text { stratum (Living Floor 2) (ethnostratigraphic). }\end{array}$} \\
\hline & & & -10YR 5/1 & \\
\hline 4 & $36-92 \mathrm{~cm}$ & $\mathrm{C}$ & 10YR 8/3 & $\begin{array}{l}\text { White dune sand, finely textured very loosely consolidated, } \\
\text { with calcium carbonate inclusions in the upper levels (eolian } \\
\text { deposit). }\end{array}$ \\
\hline \multirow[t]{2}{*}{3} & \multirow[t]{2}{*}{$78-145 \mathrm{~cm}$} & \multirow[t]{2}{*}{ Bwn } & $7.5 \mathrm{YR} 6 / 4$ & \multirow{2}{*}{$\begin{array}{l}\text { Pink quartz sand finely textured well consolidated, free of } \\
\text { inclusions (Living Floor 1) (ethnostratigraphic). }\end{array}$} \\
\hline & & & -7.5 YR $7 / 4$ & \\
\hline \multirow[t]{2}{*}{2} & \multirow[t]{2}{*}{$64-134 \mathrm{~cm}$} & \multirow[t]{2}{*}{ Bwk } & $2.5 \mathrm{Y} 8 / 6$ & \multirow{2}{*}{$\begin{array}{l}\text { Yellow sand finely textured, loosely consolidated, with calcium } \\
\text { carbonate small pebble inclusions }(3 \mathrm{~mm}-1 \mathrm{~cm}) \text { (eolian deposit) }\end{array}$} \\
\hline & & & $-2.5 Y 8 / 8$ & \\
\hline \multirow[t]{2}{*}{1} & \multirow[t]{2}{*}{$97-\mathrm{cm}$} & \multirow[t]{2}{*}{$\mathrm{C}$} & $5 Y 8 / 2$ & \multirow{2}{*}{$\begin{array}{l}\text { Olive white sand, finely textured, moderately packed, with } \\
\text { small }(3 \mathrm{~mm}-2 \mathrm{~cm}) \text { beach pebbles and calcium carbonate } \\
\text { inclusions (fluvial deposit). }\end{array}$} \\
\hline & & & $-5 Y 8 / 4$ & \\
\hline \multirow[t]{2}{*}{$6 a$} & \multirow[t]{2}{*}{$5-28 \mathrm{~cm}$} & \multirow[t]{2}{*}{ Ap } & 10YR 8/2 & \multirow{2}{*}{$\begin{array}{l}\text { Fine white ash with carbon inclusions. A substratum is a resul } \\
\text { of recent agricultural activity (ethnostratigraphic). }\end{array}$} \\
\hline & & & -10 YR $8 / 3$ & \\
\hline \multirow[t]{2}{*}{$5 a$} & \multirow[t]{2}{*}{$6-72 \mathrm{~cm}$} & \multirow[t]{2}{*}{ Bwt } & 10YR 8/1 & \multirow{2}{*}{$\begin{array}{l}\text { Densely packed pale white clay fine textured, free of inclusions, } \\
\text { hard and densely packed. Represents a prepared clay surface } \\
\text { (ethnostratigraphic). }\end{array}$} \\
\hline & & & -10 YR 8/4, & \\
\hline \multirow[t]{2}{*}{$5 b$} & \multirow[t]{2}{*}{$65-80 \mathrm{~cm}$} & \multirow[t]{2}{*}{$\mathrm{Bw}$} & $10 \mathrm{YR} 3 / 6$ & \multirow{2}{*}{$\begin{array}{l}\text { Dark brown ashy loam finely textured, the result of post- } \\
\text { depositional weathering and decomposition of Stratum } 5 \\
\text { (ethnostratigraphic). }\end{array}$} \\
\hline & & & $-10 \mathrm{YR} 4 / 2$ & \\
\hline
\end{tabular}

\begin{tabular}{ccccc}
\hline $5 \mathrm{c}$ & $57-74 \mathrm{~cm}$ & various & Animal burrow & \\
\hline $4 \mathrm{a}$ & $37-45 \mathrm{~cm}$ & Bk1 & 10YR 7/4 & $\begin{array}{l}\text { Very pale brown, extremely hard calcrete conglomerate, calcrete } \\
\text { sand with no sublayers identified in profile, some inclusions } \\
\text { (post-depositional weathering). }\end{array}$ \\
\hline
\end{tabular}

\begin{tabular}{ccccl}
\hline $3 \mathrm{a}$ & $57-145 \mathrm{~cm}$ & $\mathrm{Bk} 2$ & 10 YR 6/4 & $\begin{array}{l}\text { Light yellowish brown, extremely hard calcrete nodules high } \\
\text { clay fraction (post-depositional weathering). }\end{array}$ \\
\hline $1 \mathrm{a}$ & $57-68 \mathrm{~cm}$ & $\mathrm{Bt}$ & $5 \mathrm{Y} \mathrm{6/4}$ & $\begin{array}{l}\text { Shell lag deposit, hard yellow olive clay finely textured with } \\
\text { shells inclusions throughout (eroded deposit). }\end{array}$ \\
\hline $1 \mathrm{~b}$ & $65-82 \mathrm{~cm}$ & $\mathrm{Bg}$ & $2.5 Y$ 6/8 & $\begin{array}{l}\text { Light olive yellow clay finely textured with organic nodules, } \\
\text { high clay fraction, and shell inclusions on the bedding plane } \\
\text { (eroded deposit). }\end{array}$ \\
\hline $1 \mathrm{c}$ & $45-150 \mathrm{~cm}$ & $\mathrm{Bt}$ & 10 YR 8/3 & $\begin{array}{l}\text { Fine fraction white clay with extensive small to medium sized } \\
\text { beach pebble inclusions (eroded deposit). }\end{array}$ \\
\hline $1 \mathrm{~d}$ & $57-145 \mathrm{~cm}$ & $\mathrm{Bk} 3$ & 10 YR 6/4 & $\begin{array}{l}\text { Light yellowish brown, extremely hard calcrete conglomerate } \\
\text { made up of calcified sand, no inclusions, but nodules and } \\
\text { internodular fillings (post-depositional weathering). }\end{array}$ \\
\hline $1 \mathrm{e}$ & $57-145 \mathrm{~cm}$ & $\mathrm{Bk} 4$ & $2.5 \mathrm{YR} \mathrm{5/4}$ & $\begin{array}{l}\text { Reddish brown, extremely hard calcrete internodular, filling has } \\
\text { arlatively high clay fraction (post-depositional weathering). }\end{array}$ \\
\hline
\end{tabular}

Note: All soil colors are classified using the Munsell Soil Color Chart 1975 Edition. Differences in color were sometimes noted within a particular stratum, and these designations were the most characteristic for the stratum as a whole. Depths are given as below datum, and indicated as minimum and maximum levels which of course varied in different areas of the excavations. 
roughly contemporaneous with those recorded in the nearby lake cores and archaeological sites in northern coastal Peru supporting the hypothesis that it is a result of El Niño.

Stratum 5 extends between $10 \mathrm{~cm}$ to just under a meter in depth, with an average thickness of roughly $35 \mathrm{~cm}$ (see Table 6). Stratum 5 constitutes the existing land surface over $75 \%$ of the total area of the site and represents the primary occupation floor. Architectural features associated with the northwest earthen mound measure $75 \mathrm{~m}$ north-south by $47 \mathrm{~m}$ east-west and approximately $1.5 \mathrm{~m}$ high (Staller 1994:319, 2001a). Few cultural remains were found in the lower and middle levels, indicating it was kept meticulously clean - a cultural pattern consistent with ceremonial centers in other regions of the Andes. Nevertheless, the mound was covered with oyster shell and sherds during the stratum 5 abandonment and later stratum 6 reoccupation, perhaps intentional to protect the mound from rising floodwater (Staller 1994).

Evidence of disconformity in the lower interface of stratum 5 may be a result of depositional events (see Figures 10-11). Most archaeological features were in the upper $10 \mathrm{~cm}$ and either ritual or architectural including two complete oval or elliptically shaped daub platforms, four burials, numerous clay-lined and sealed offering pits, retaining walls, and post impressions (Staller 1994, 2001b; Ubelaker and Bubniak Jones 2002). Ceramic diagnostics and ${ }^{14} \mathrm{C}$ dates suggest occupation corresponding to the final portion of the culture sequence, ca., 2200-1450 B.C. ${ }^{9}$ (see Table 4).

A very lightly to strongly carbonate massive duricrust formation was identified on living floor 2, stratum 5 and under stratum 6 on the SW side of the platform (see Figure 6b). The 5 to $10 \mathrm{~cm}$ thick calcified quartzitic sand crust is made up of soft and friable silicified sands with no apparent nodular development indicating this represents a silcrete the result of superficial diagenesis (Goudie 1973:8). Silcrete formations are related to seasonal fluctuations in climate resulting in the chemical alteration of sediments through hydration (ibid.:112). They form near stream channels in areas with a high water table - characteristics that describe the coastal setting and geomorphology (ibid.:17, 36). Silcrete

$9 \quad$ Like other earthen mounds at Valdivia ceremonial centers, the NW platform was also a burial mound (see e.g., Lathrap et al. 1975; Marcos 1988; Marcos et al. 1976) crusts may be eolian, as the constant abrasion of fine-grained quartz sands lead to concentrations of fine siliceous dust, which is susceptible to solution and alteration by fog dew (garúa) or changes in groundwater (ibid.:140-141).

This formation suggests the earthen mound and surrounding area underwent climatic fluctuations that included high wind velocities and a rise in ground water levels - factors consistent with the onset of an El Niño which first effected the adjacent highlands in the middle of what is normally the dry season i.e., July or August. Presumably, after stratum 5 abandonment increased precipitation may have raised the ground water immediately before inundation by flooding and/or associated seismic activity, and site burial through tidal asymmetry. Environmental reconstruction suggests the area to the north was the side facing the prevailing winds and the main lagoon. During periods of intense precipitation, elevated lunar tides may have left sea salts in solution on what was the foreshore and salt flats. Post-depositional weathering or evapotranspiration later crystallized these marine salts because the evaporation rate is greater and the ground water richer in dissolved sea salts resulting in duricrust formation, an interpetation consistent with such climatic and geomorphological processes.

The uppermost layer, stratum 6 , is dark brown silt loam ranging between $10 \mathrm{~cm}$ to $58 \mathrm{~cm}$ thick, and represents a flood deposit, possibly combined with seismic activity (Keefer and Moseley 2004; Keefer et al. 2003). Recent Mega-El Niño events indicate this region is highly susceptible to denudation and inundation and that coastal flooding is related almost exclusively to such events. Moreover, research on El Niño related effects associated with seismic activity indicate that when such phenomena occur together, they can produce landslides, increased runoff and sediment transport during post earthquake rainstorms (Keeler and Moseley 2004:10878, 10881). Ceramic diagnostics and ${ }^{14} \mathrm{C}$ dates from stratum 5 suggest stratum 6 was deposited at $\sim 1450$ B.C. (see Table 4 ). Stratum 6 has the appearance of alluvium and is loosely consolidated and clearly distinct in color and texture from the underlying strata. Environmental reconstruction suggests the area of the site faced the main estuary lagoon and artifacts from stratum 6 were from deposits disturbed by bioturbation through plant root action or recent human activity. A horizontal feature interface representing a plow zone, noted as thin lenses of burned ash (Sublayer 6a), extend 
to $15 \mathrm{~cm}$ in depth in several areas (see Figure 11). Anecdotal evidence indicates this was the result of recent small-scale slash and burn maize agriculture. The only area where such cultivation was carried out was where stratum 6 represented the existing land surface.

Evidence from the nearby Laguna Pallcacocha lake cores record an El Niño event date to c. 1500 B.C. which, given the apparent high levels of sediment load, may have been accompanied by or occurred subsequent to seismic activity (Jordan et al. 1983:figures 1 and 2; Rodbell et al. 1999:figure 3; Moy et al. 2002:164, figure 1; Hansen et al. 2003:102). Tectonic activity associated with the Atacazo Volcano in the Jama Valley, Manabí Province date to 1680 to 1550 B.C (Isaacson 1994:135). Subsequently, Hansen et al. (2003:102) report a $1 \mathrm{~cm}$ thick tephra layer from this lake core related to volcanic activity dated to $2500 \mathrm{cal}$. B.P and another just above it to 2200 cal. B.P. (Rodbell et al. 2002:figure 3). Such volcanic activity did not have a dramatic effect in this region as no visible evidence of tephra deposits were identified in regional survey, with pre-Hispanic deposits readily discernible on the existing land surface and in cross section on exposed profiles. The central and northern highlands of Ecuador ranging between $5^{\circ}$ North to $3.5^{\circ}$ South Latitude are the regions with the most volcanic activity. Ceramic diagnostics and ${ }^{14} \mathrm{C}$ dates from stratum 5 suggest a possible correlation between the $2500 \mathrm{cal}$. BP eruption and other events of the same approximate age, and site abandonment.

These internally consistent lines of evidence infer stratum 6 was deposited as a result of a flood associated with tidal asymmetry, possibly combined with and/or closely following seismic activity. The stratum is anomalous in the sense that it is restricted to only a portion of the site and largely absent in the area to the west, where the existing surface consists of the fine white sand similar to stratum 4. Research on seismic activity in association with El Niño events in other Andean regions has shown that anomalous flood deposits may be a product of seismic landscape shattering and El Niño related floods and when these occur in combination, they result in particularly large runoff and sediment transport (Keefer and Moseley 2004:10882).

In addition, adaptive shifts in response to bioturbation were also noted in settlement patterns. Perhaps the most dramatic evidence is the total disappearance of oyster (Ostrea columbiensis L.) from all Middle and Late Formative sites identified in regional survey. Barrier reefs upon which such oyster beds existed were probably buried by excessive runoff of fluvial sediments and/or uplift and destroyed (Nummedal 1983). Seismic activity would have created extraordinarily high sediment loads in the coastal stream channels ${ }^{10}$. Uplift would have exposed at least some of the beds to the elements and to human and terrestrial predators, as this is a shallow estuarine environment. Moreover, stratum 6 represents the only transgressive unit in an otherwise progradational stratigraphic sequence (Staller 1994:table 13).

The permeability of eolian sediments affected the geomorphology of the various strata identified in the excavations. The coarser grain sediments that make up stratum 6 are more permeable than the finer grained sands and ashy loam below. Consequently, flow of rainwater percolating through the lower stratigraphic deposits is more restricted (Holliday 1990:536). Differences in the permeability of the uppermost layer and the grey ashy loam below it are reflected by gaps, or separations of as much as $5 \mathrm{~cm}$, related to the buildup of rain water at the buried stratum 6-5 interface. The poorly drained sediments that make up the lower layers (4-1) is further evident by the presence of decomposed or hydrated organic matter throughout.

In summary, the stratigraphy is characterized by well-defined interfaces with clear differences in color, texture and composition among the various layers. The brown silt and ashy loam, strata 6 and 5 respectively, essentially preserving the overall integrity and stability of the underlying strata. The moist and fine grain sands quickly lost their overall structure when exposed to the natural elements, making the delineation archaeological features extending into the lower sand layers (strata 4 to 1 ). Stratigraphic evidence at La Emerenciana and dates from nearby lake cores support the interpretation of repeated site abandonment due to climatic upheaval and/or geomorphological changes consistent with El Niño. Layers 4 to 1 represent seaward components of a barrier coastline, shoreface, foreshore, backshore, and dune facies respectively. With

10 Oyster shells are totally absent from Late Formative sites. Detailed research of several partially exposed shell middens standing over twelve meters high near Huaquillas indicate a total absence of oyster shell over a thousand year time period (Staller 2000). 
the exception of uppermost layer stratum 6 , the stratigraphic sequence, is consistent with progradational coastal development. Uppermost stratum 6 represents a transgression consistent with a low energy estuary with deposition due to flooding, tidal wave asymmetry, and/or a dramatic influx of fluvial sediments, an indicator of El Niño and also an indication such climatic events may have been associated with seismic activity (Arntz 1986:7, 18-19; Keefer et al. 2003:figures 2, 3; Keefer and Moseley 2004).

\section{Shell Frequencies: Analysis of Minimum Number of Individuals (\% MNI)}

Minimum number of individual (MNI) shellfish counts from the midden on the northern portion of the mound provides additional lines of internally consistent evidence with the stratigraphic and geomorphological data. A shell midden on the northern edge indicate oyster was the most intensively exploited species this on the basis of \%MNI frequencies from Profile A and Trench A and B (Figures 13-14; Tables 7a-d, 8a-d). Multidisciplinary evidence indicates this is a single depositional event, perhaps to protect the retaining walls surrounding the north or seaward side of the earthen mound. In order to minimize sample bias shell species were collected from randomly selected excavation units. Oysters were most intensely exploited in stratum 5 , followed by Pointed Venus Clam from coastal lagoons and mudflats, and Protothaca Clam buried in nearby mudflats or coastal bays (Olsson 1961:297-298; Keen 1971:190,193). Such distinct species provide indirect indications of adaptive shifts, and geomorphological or environmental changes related to El Niño. Moreover, a $40 \%$ reduction in the size of oyster specimens in stratum 6 indicates the barrier reef was affected by geo-climatic changes ${ }^{11}$.

Six hundred oysters were randomly selected from a predetermined number of arbitrary selected excavation units from stratum 5 and 6, 300 from stratum 6 and another 300 from stratum 5. Oysters from stratum 5 averaged between 90 and $125 \mathrm{~mm}$ long, while those in stratum 6,45 to $70 \mathrm{~mm}$. The $40 \%$ size reduction was visibly evident in excavation and on floor 2 surface remains. Constricted growth rings were evident on the majority of

11 Length of shell specimens refers to the measurement of the dorsal to the ventral surface edge. bivalves, particularly Anadara, or pata de mula (A. grandis Broderip \& Sowerby) and simile ark or concha prieta (A. tuberculosa Sowerby) providing direct evidence of climatic perturbation supporting the hypothesis that strata 5 and 6 abandonment were a result of climatic change related to El Niño events. During such climatic perturbations alluvial and fluvial sediments can accumulate very rapidly (Hayes 1975; Carter 1988). Current understanding of the phenomenon indicates all flooding in this region is a result of El Niño, regardless of intensity and/or duration. Ecotones or transitional environmental zones are prone to draught, with short growing cycles, and nine-month dry season making them highly susceptible to El Niño related perturbations. A portion of the mound was buried by sediment with abandonment of stratum 5, reflecting a major El Niño event associated with seismic activity. However, earlier and later evidence of El Niño provide no evidence whatsoever of coastal transgression, but rather large-scale continuous progradation (Staller 1994).

Evidence of prehistoric El Niños may also be derived from variation in the shell species frequencies from archaeological sediments. Shell frequencies were determined by raw counts according to species. When total counts were uneven, the extra bivalve was counted as a complete individual. Once categorized and quantified by species totals were broken down to percentages of minimum numbers of individuals (\%MNI). These frequencies were segregated by arbitrary increments with Trench B and on the basis of natural stratigraphic layers elsewhere (Figures 13, 14, Tables 7a-d, 8a-d). Differences in mollusk species in archaeological sediments have been reported as evidence of modifications to aquatic habitats as a result of cultural preference and/or natural factors such as climate (Stein 1990, 1992a, 1992b). Economic shifts and/or climatic change was inferred: 1) a cultural bias for particular food species and, 2) that various taxa inhabited the area during site occupation (Tables 7a-d). Potential factors complicating the statistical reliability, such as sea level changes, geomorphological, and environmental change (all side effects of El Niño) were considered at the outset of this analysis.

A random sample of shells was selected from the surface, identified according to species and assessed by relative frequencies. Only five species were used for comparison, since the low frequencies of some specimens made them statistically insignificant. The 


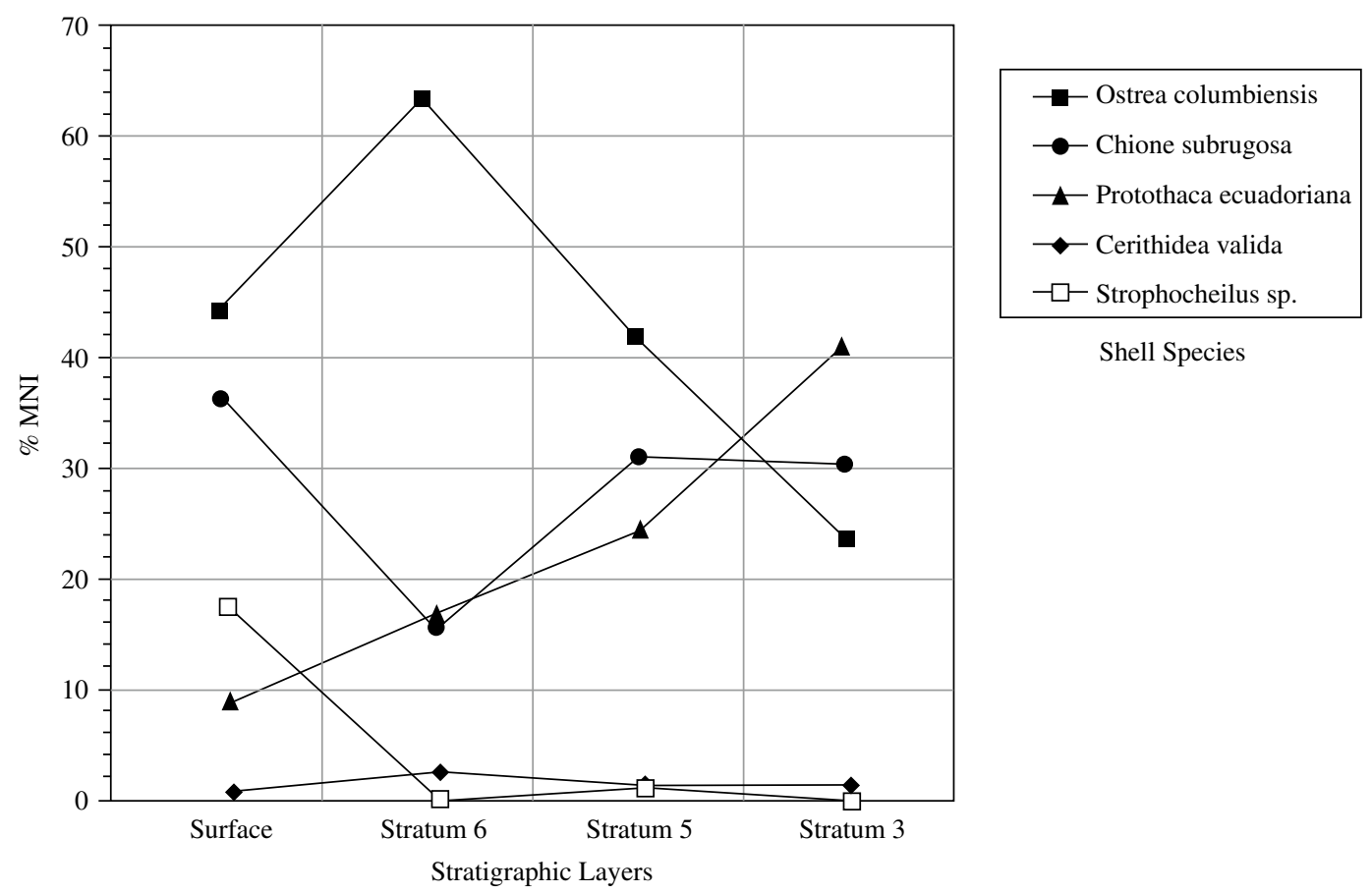

Figure 13. Percentage frequencies by minimum number of individuals (\%MNI) by stratigraphic layer.

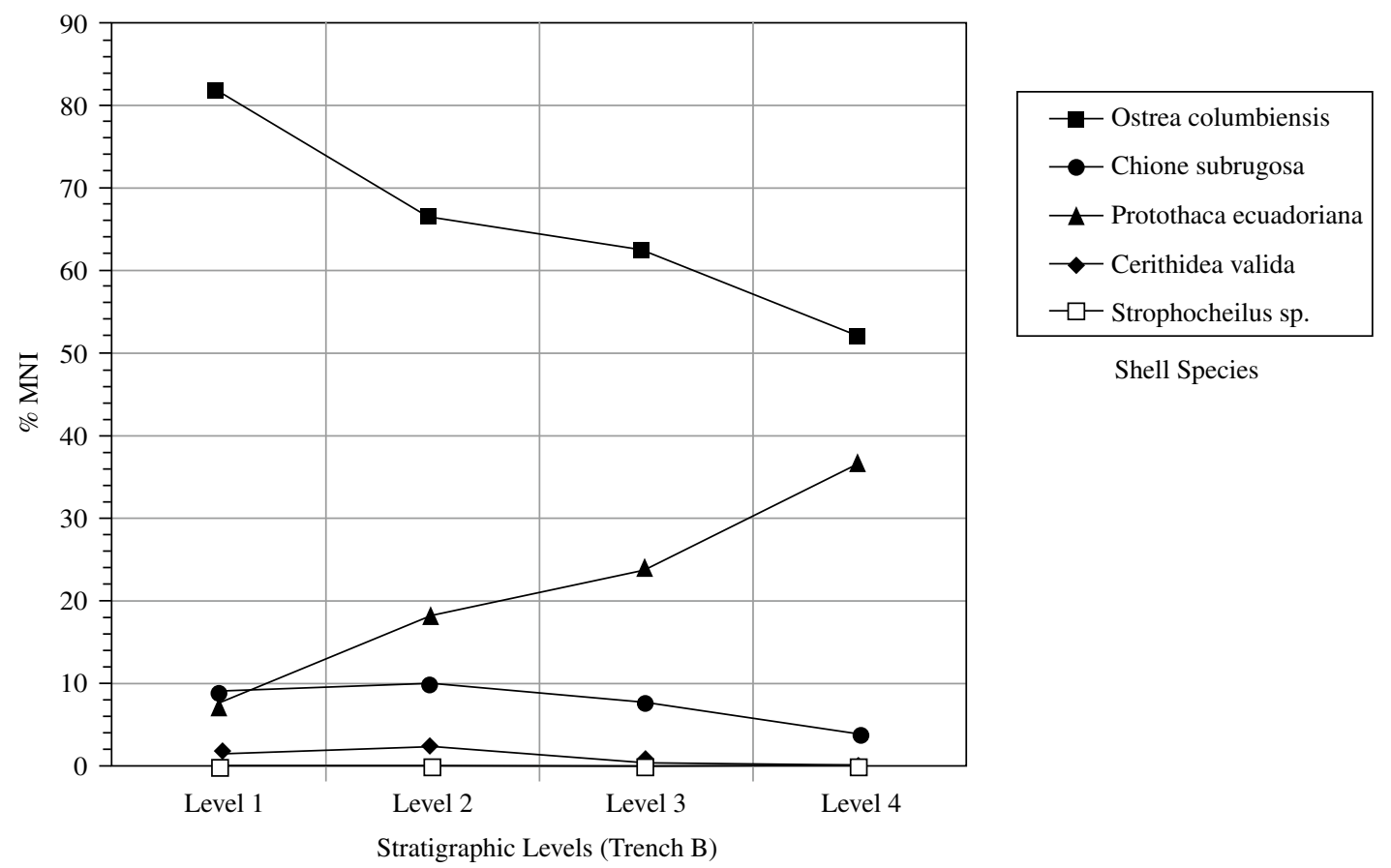

Figure 14. Percentage frequencies by minimum number of individuals (\%MNI) by levels or arbitrary increments (Trench B). 
raw counts indicated nutritional bias for Oysters (Ostrea columbiensis L.), pointed Venus clams (Chione subrugosa Wood), and Protothaca clams (Protothaca ecuadoriana Rafinesque) (Tables 7a-d). In more inland settlements, Simile Ark (Anadara

Table 7A. Shell frequencies: Surface

\begin{tabular}{lrrrr}
\hline \multicolumn{1}{c}{ Species } & $\begin{array}{c}\text { Total } \\
\mathrm{N}^{\mathbf{0}}\end{array}$ & MNI. & $\begin{array}{c}\text { Total } \\
(\%)\end{array}$ & $\begin{array}{c}\text { MNI. } \\
(\%)\end{array}$ \\
\hline Ostrea columbiensis & 575 & 288 & 44.50 & 44.17 \\
Chione subrugosa & 471 & 236 & 36.45 & 36.19 \\
Protothaca ecuadoriana & 111 & 56 & 8.59 & 8.58 \\
Strophoceilus sp. & 121 & 121 & 9.37 & 16.99 \\
Cerithidea valida & 5 & 5 & 0.39 & 0.76 \\
Anadara similis & 4 & 2 & 0.30 & 0.30 \\
Anadara grandis & 3 & 2 & 0.24 & 0.30 \\
Polinices sp. & 2 & 2 & 0.15 & 0.30 \\
Total & 1292 & 712 & 99.99 & 99.99 \\
\hline
\end{tabular}

Table 7b. Shell frequencies: Stratum 6

\begin{tabular}{lrrrr}
\hline \multicolumn{1}{c}{ Species } & $\begin{array}{c}\text { Total } \\
\mathrm{N}^{\mathbf{0}}\end{array}$ & MNI. & $\begin{array}{c}\text { Total } \\
(\%)\end{array}$ & $\begin{array}{c}\text { MNI. } \\
(\%)\end{array}$ \\
\hline Ostrea columbiensis & 8991 & 4496 & 64.86 & 63.34 \\
Chione subrugosa & 2196 & 1098 & 15.84 & 15.46 \\
Protothaca ecuadoriana & 2367 & 1184 & 17.07 & 16.68 \\
Cerithidea valida & 174 & 174 & 1.25 & 2.45 \\
Strophoceilus sp. & 4 & 4 & 0.02 & 0.05 \\
Anadara tuberculosa & 41 & 21 & 0.29 & 0.29 \\
Anadara similis & 77 & 39 & 0.55 & 0.55 \\
Anadara grandis & 48 & 24 & 0.34 & 0.33 \\
Anadara obesa & 1 & 1 & 0.007 & 0.01 \\
Polinices sp. & 45 & 45 & 0.32 & 0.63 \\
Mactra augusta & 7 & 4 & 0.05 & 0.05 \\
Dosinia dunkeri & 5 & 3 & 0.03 & 0.04 \\
Cirripides sp. & 2 & 2 & 0.01 & 0.02 \\
Olivia callosa & 1 & 1 & 0.007 & 0.01 \\
Cerithum sp. & 1 & 1 & 0.007 & 0.01 \\
Cardita magastropha & 1 & 1 & 0.007 & 0.01 \\
Total & 13861 & 7098 & 100.65 & 99.92 \\
\hline
\end{tabular}

Table 7c. Shell frequencies: Stratum 5, Floor 2

\begin{tabular}{|c|c|c|c|c|}
\hline Species (Local Name) & Popular Name & Total No. & Total $(\%)$ & MNI.(\%) \\
\hline Ostrea columbiensis (ostión) & Mangrove Oyster & 7906 & 3953 & 42.01 \\
\hline Chione subrugosa (almeja bajera) & Pointed Venus & 5866 & 2933 & 31.17 \\
\hline Protothaca sp.(almeja (llorona) & Protothaca Clam & 4442 & 2221 & 24.33 \\
\hline Cerithidea valida (churo) & Valide Horn & 133 & 133 & 1.38 \\
\hline Strophoceilus sp. (caracol de monte) & Land Snail & 100 & 100 & 1.06 \\
\hline Anadara similis (concha prieta) & Simile Ark & 130 & 66 & 0.70 \\
\hline Anadara grandis (pata de mula) & Grandis Ark & 44 & 22 & 0.23 \\
\hline Anadara tuberculosa (concha prieta) & Tuberculosa Ark & 40 & 20 & 0.21 \\
\hline Anadara emarginata & Emarginate Ark & 1 & 1 & 0.01 \\
\hline Polinices sp. & Moon Shell & 22 & 22 & 0.23 \\
\hline Dosinia dunkeri (almeja disco) & Disk Dosinia & 15 & 8 & 0.08 \\
\hline Mactra augusta & Mactra Clam & 12 & 6 & 0.06 \\
\hline Crepidula marginalis & Slipper Shell & 5 & 5 & 0.05 \\
\hline Cerithium adustum & Horn Shell & 4 & 4 & 0.04 \\
\hline Strombus galeatus & Winged Conch & 3 & 3 & 0.03 \\
\hline Litorina sp. (caracol mangle) & Periwinkle & 2 & 2 & 0.02 \\
\hline Neritina latissima (caracol multicolor) & Virgin Nerite & 2 & 2 & 0.02 \\
\hline Olivia callosa & Pacific White Venus & 3 & 2 & 0.02 \\
\hline Tagelus sp. (nabajas) & Jacknife Clam & 2 & 1 & 0.01 \\
\hline Polymesoda inflata & Inflata Marsh Clam & 1 & 1 & 0.01 \\
\hline Nassarius sp. & Dog Whelk & 1 & 1 & 0.01 \\
\hline Mytella strigata (mejillón) & Strigata Mussel & 1 & 1 & 0.01 \\
\hline Olivella sp.(carcol playero) & Dwarf Olive & 1 & 1 & 0.01 \\
\hline Cirripides sp. (cirrópodo) & Barnacle & 1 & 1 & 0.01 \\
\hline Spondylus princeps (mullu) & Thorny Oyster & 1 & 1 & 0.01 \\
\hline Total & & 18736 & 9409 & 99.99 \\
\hline
\end{tabular}

tuberculosa Sowerby), constituted the predominant species during the later formative sites, but were rare in the excavations suggesting interaction. Local fishermen related that when packed wet in salt water, Simile Ark may be carried for several days without spoiling. Their abundance at formative sites indirectly reflects the importance of the mangrove forest and maritime resources. Their 
Table 7d. Shell frequencies: Stratum 3

\begin{tabular}{lrrrr}
\hline \multicolumn{1}{c}{ Species } & $\begin{array}{r}\text { Total } \\
\mathrm{N}^{\mathrm{o}}\end{array}$ & MNI. & $\begin{array}{r}\text { Total } \\
(\%)\end{array}$ & $\begin{array}{c}\text { MNI. } \\
(\%)\end{array}$ \\
\hline Ostrea columbiensis & 816 & 408 & 24.02 & 23.69 \\
Chione subrugosa & 1054 & 527 & 31.03 & 30.60 \\
Protothaca ecuadoriana & 1420 & 710 & 41.81 & 41.23 \\
Cerithidea valida & 25 & 25 & 0.73 & 1.45 \\
Anadara tuberculosa & 41 & 22 & 1.20 & 1.27 \\
Anadara similis & 4 & 2 & 0.11 & 0.11 \\
Anadara grandis & 6 & 3 & 0.17 & 0.17 \\
Anadara obesa & 2 & 1 & 0.05 & 0.05 \\
Anadara labiosa & 2 & 1 & 0.05 & 0.05 \\
Polinices sp. & 17 & 17 & 0.50 & 1.22 \\
Mactra augusta & 4 & 2 & 0.11 & 0.11 \\
Tagelus irregularis & 1 & 1 & 0.02 & 0.05 \\
Nassarius sp. & 1 & 1 & 0.02 & 0.05 \\
Crepidula marginalis & 1 & 1 & 0.02 & 0.05 \\
Oliva callosa & 2 & 1 & 0.05 & 0.05 \\
Total & 3396 & 1722 & 99.89 & 99.15 \\
\hline
\end{tabular}

absence at La Emerenciana surprising because Anadara impressed cambered jars are emblematic of particular diagnostics in the Jelí Phase pottery complex (Figure 15a) $)^{12}$.

Land snails (Strophocelius spp. Pilsbry) called "churo" are adapted to trees or the surfaces of mud flats beyond the limits of the high tide. They are a marginal food source and only exploited during periods of resource scarcity. Valide Horn Conch (Cerithidea valida Swainson) are buried in the brackish mud flats at high tide level or entirely out of water on reeds and twigs, and only consumed when more favorable species are unavailable. Both are indicators of environmental stress and anecdotal evidence a multipurpose species, and sometimes ground into lime for chewing coca leaves, or soaking maize kernels. These specimens were restricted to the uppermost $10 \mathrm{~cm}$ of stratum 5 , thus potential climatic and environmental indicators when the region was undergoing geo-climatic alteration during abandonment (Staller 1994).

Results indicate distinct frequencies relative to the stratigraphic layers. Stratum 3, floor 1 data

12 The only other late Valdivia locality with Anadara impressed diagnostics known is the ceremonial center of San Lorenzo del Mate in the Guayas Basin. San Lorenzo is contemporaneous with La Emerenciana and has an eight-meter high earthen mound, the earliest mound of this scale along the Ecuadorian coast. Anadara impressed the diagnostics were identified in 2003 in the course of surface survey with my colleague and friend the late Ecuadorian archaeologist Lcdo. Felipe Cruz Mancilla. indicate Protothaca Clam from the mudflats of coastal bays have the highest frequencies, followed by Venus Clam from the lagoons and mud flats, and finally by oysters attached to barrier reefs and mangrove prop roots. The environment appears to have been on or near a bay, with mudflats and direct access to a barrier reef. A 19\% decline in Protothaca clam frequencies in stratum 5 may reflect gradual environmental changes from a bay into a barrier estuary (see Figure 13). Sand dunes and a fossil beach ridge 500 meters north of La Emerenciana are result of an El Niño associated with the deposition of stratum 6. Solely the uppermost layer includes red on white-banded diagnostics (Figure 15b). Reduction in these clams may also be related to an increase in white sandy dune sediments into the coastal bay due to the formation of dune ridges. Increase in sandy sediments in the intertidal zone could have buried the clams. Stability in Pointed Venus Clam frequencies suggest the lagoons scattered through both sides of the coastal streams, and particularly those behind the barrier reef and mangrove islands, continued to be exploited.

Relative changes in the \%MNI frequencies and grain size analysis of stratum 6 support a hypothesis of rapid geomorphological change. Smaller oysters and constricted growth rings on most bivalves found on the surface are consistent with longer and higher levels of precipitation, excessive drainage runoff, and swift or sudden introduction of large volumes of fresh water and sandy sediment. El Niño can rapidly bury large areas of the coast in silt and mud, suppressing tidal currents and creating tidal wave asymmetry, which significantly increases the sediment load (Carter 1988; Cane 1983). Slight increases in Valide Horn frequencies on the surface of stratum 6 suggest less favored food species were exploited supporting geo-climatic changes. Grain size, stratigraphic and ceramic evidence suggest the brown silt (stratum 6) may represent a flood deposit that covered over the primary occupation layer in the northwest part of La Emerenciana. This depositional event occurred rapidly, inundating the site, perhaps explaining final site abandonment.

In conclusion, ceramic diagnostics in and on stratum 6 also infer final occupation was temporally restricted to a period of less than fifty years (Staller 1994:137-142). Effects of El Niño-related activity are evident by the total extinction of oysters at Middle and Late Formative sites. Beach ridge formation is also related to El Niño events, which 


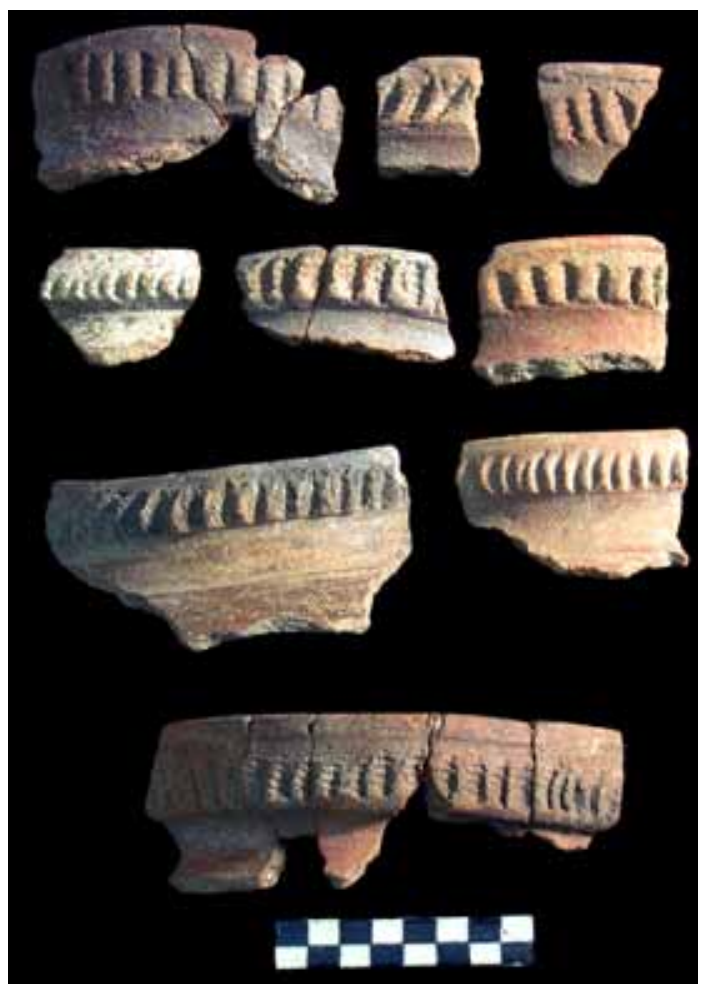

Figure 15a. Jelí Phase cambered jars rims with Anadara impressed motifs. Such cambered jar fragments were found at all eleven Valdivia sites identified in regional survey and constituted the most commonly identified diagnostics in the excavations at $\mathrm{La}$ Emerenciana. The low numbers of Anadara spp. shell in the excavations suggest they may have been traded inland. Replication experiments have demonstrated that the impression could only have been made by the species Anadara tuberculosa Sowerby.

can rapidly introduce volumes of sandy sediments into an estuary, burying and changing the configuration of ponds and lagoons located along the coast and further inland. A 17\% decline in Pointed Venus frequencies may reflect changes in lagoonal and mud flat habitats, perhaps flooding or periodic inundation of coastal lagoons by fresh water incursion. Continued decreases of Protothaca Clam may be due to continued silting of an ancient arcuate bay once located due west of the site. One of the most striking changes is an increase in land snails in surface samples, suggesting resource scarcity during final site abandonment (see Figure 13). Once the coastal waters receded this species would have been available in the trees and surrounding mud flats at the high tide line. Significant increases in Pointed Venus suggest this low wave energy estuary and the coastal lagoons quickly returned to normal. Decline in frequencies of Protothaca Clam infers continued

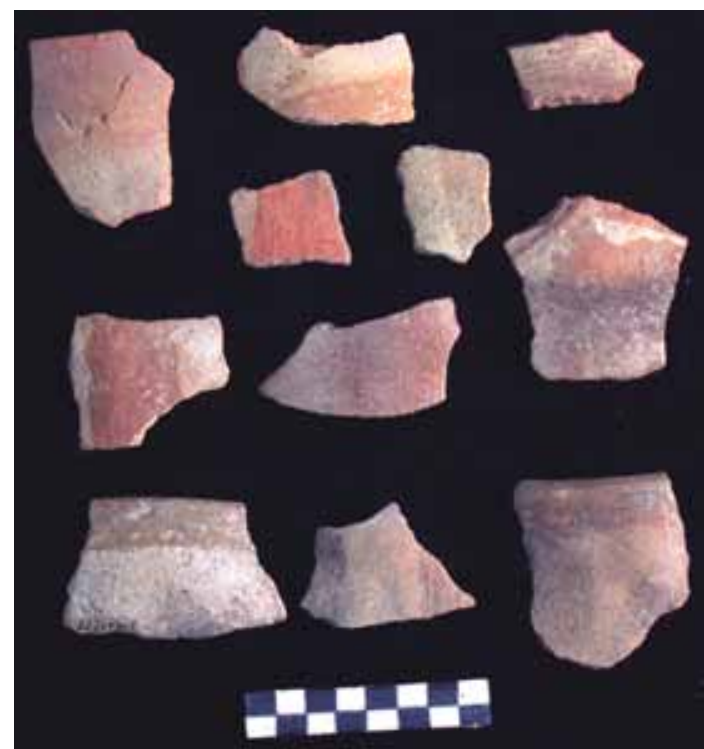

Figure 15b. Jelí Phase red on white-banded diagnostics. The redon-white banded stylistic tradition has generally been associated with the early pottery complexes of southern highland Ecuador and northern highland and coastal Peru. Its earliest appearance pertains to late Valdivia culture in coastal El Oro Province.

environmental change from a coastal bay protected by a barrier reef, to a barrier island estuary. A $20 \%$ decline in oysters on the surface also mirrors such environmental changes. Extinction of oysters for a period of over 1200 years after the final stratum 6 abandonment from this region is another indicator of the geological scale of destruction to the estuary and the barrier reef brought on by increases in El Niño related activity (Staller 1994).

\section{Analysis of Shell Remains from Arbitrary Levels (Trench B)}

Since the smallest natural unit of analysis was too large to detect changes in the vertical distribution of shell species or artifacts, seashells from Trench B were excavated in arbitrary $15 \mathrm{~cm}$ increments, thus some mixing was presumed (see Figure 14). These raw data are not directly comparable to those from natural layers. Shell frequencies in the midden corresponded exclusively to strata 5 and 6 . Trench B \%MNI oysters frequencies indicate a $30 \%$ increase in the uppermost levels and a $20 \%$ decrease in Protothaca Clam, consistent with shell frequencies for strata 5 and 6. Pointed Venus Clam slightly increases in level 2, but then decreases in uppermost level 1 to less than $10 \%$ of the total, 
while frequencies from natural stratigraphic layers average about $25 \%$ in stratum 5 . Such differences may be related to sample size (see Tables 8a-d). Pointed Venus clams would be more intensely exploited during periods of resource scarcity. The frequencies further indicate lagoonal environments remained stable, although they were a relatively minor resource (see Figures 13 and 14).

Trench B shell frequencies are reliable indicators of environmental change, as their overall distribution is similar to \%MNI from strata 6 and 5 (see Tables $7 \mathrm{~b}-\mathrm{c}$ ). Congruence in frequencies for stratum 6 and those from level 1 may indicate that the uppermost level was associated with the final occupation. Oyster counts from both stratigraphic layers and arbitrary levels indicate they were the most highly exploited and even more intensely exploited during stratum 5 abandonment. Results indicate shell in the upper levels of Trench B represent a single continuous deposit, the product of the final occupation of stratum 5. The uppermost $15 \mathrm{~cm}$ may be associated with the brief stratum 6 occupation. However, stratum 6 was not visible in cross section, due to the large quantities of bivalves and sherds (Staller 1994:345). Artificial retaining walls and descending terraces were recorded in the Trench B excavation. The construction of artificial terraces to demarcate sacred space is common in the Andes particularly early huacas in the highlands (Hocquenghem et al. 1993). Various lines of evidence indicate two major El Niño events associated with site abandonment dated to c. 2150 B.C. and another dated to c. 1450 B.C. resulting in final abandonment. Auxiliary lines of evidence from lake core data from the Cuenca valley and coastal Peru also support the timing and interpretations repeated abandonment associated with ancient El Niño events. Other supporting lines of climatological and geomorphological evidence from contemporary El Niño events also support the scale of geological and geomorphological modifications presented herein. Environmental evidence including modern analogues of devastation wrought by El Niño upon this region and provides a basis for clearer understanding of its impact upon prehistoric populations.

\section{Recent EI Niño Related Effects in Southern Coastal Ecuador}

The 1982/83 El Niño was the most devastating and destructive ever recorded in a two hundred year historic record (Rasmussen 1985; Cane 1983; Wrtki 1982; Philander 1983; Caviedes 1984; Arntz 1986; Wells 1987). Precipitation levels along the Gulf of Guayaquil totaled $3650 \mathrm{~mm}$, where the average is 1000mm (Thayer and Barber 1984:4, 10; Arntz 1986:4). Mega-El Niños usually result in intense rainfall accompanied by flooding well beyond the rainy season. During the 1982/83 event this coastal region experienced a 20 to $40 \mathrm{~cm}$ sea level rise and remained at those levels for months, followed by another sea level rise several months later (Arntz 1986:7). Between December 1982 and June 1983, seawater levels rose approximately two meters burying most of the mangrove trees and shrubs in salt, sand, and fine mud (ibid.:22). Even more severe destruction befell this region during the 1997/98 event (McPhaden 1999). The 1997/98 Mega-El Niño was comparable in intensity, yet its affects were different. Its onset was already apparent in late June/early July of 1997 rather than late December. Interactions with local fishermen along the northern shore of the Santa Elena Peninsula indicated fish capture included essentially unknown or never before seen warm water fish species, and sea birds, particularly pelicans, were dying off in great numbers ${ }^{13}$. McPhaden (1999:950) points out the SST associated with the 1997/98 event developed at such an alarming rate from June to December, that new monthly records were set along the eastern Pacific - this based upon records going back to the middle of the $19^{\text {th }}$ century. At the height of the MegaEl Niño in December, the SST anomalies averaged nearly $4^{\circ} \mathrm{C}$, the largest variation ever recorded. The SST remained anomalously high at $29^{\circ} \mathrm{C}$ in the Eastern Pacific until mid-May 1998, when trade winds abruptly returned and cold subsurface waters upwell to bring on the conditions for the La Niña to follow (McPhaden 1999:951; Vuille et al. 2000). The study area was submerged under two meters of water for a period of several weeks creating exceptional hydrological conditions that carried more sediments into the barrier island estuary in a

13 While in the Santa Elena Peninsula in late June 1997 fishermen indicated to me that tuna had moved away from the shoreline into deeper waters, and fish species foreign to this region appeared, some of which they had never seen before. During El Niños warm water species from the north migrate south into this region. Tuna swim to deeper, cooler waters, and the shoreline was scattered with the carcasses of a number of bird species, turtles and fish, an indicator that this was a mega event. 
Table 8a. Shell frequencies: Trench B Stratum 5, Level 1

\begin{tabular}{lrrrr}
\hline \multicolumn{1}{c}{ Species } & $\begin{array}{c}\text { Total } \\
\mathrm{N}^{\circ}\end{array}$ & MNI. & $\begin{array}{c}\text { Total } \\
(\%)\end{array}$ & $\begin{array}{c}\text { MNI. } \\
(\%)\end{array}$ \\
\hline Ostrea columbiensis & 4453 & 2227 & 81.78 & 80.71 \\
Chione subrugosa & 460 & 230 & 8.44 & 8.33 \\
Protothaca ecuadoriana & 410 & 205 & 7.52 & 7.43 \\
Cerithidea valida & 51 & 51 & 0.93 & 1.84 \\
Strophoceilus sp. & 1 & 1 & 0.01 & 0.03 \\
Anadara tuberculosa & 21 & 11 & 0.38 & 0.39 \\
Anadara similis & 11 & 6 & 0.20 & 0.21 \\
Anadara grandis & 20 & 10 & 0.36 & 0.36 \\
Polinices sp. & 17 & 17 & 0.31 & 0.61 \\
Mactra augusta & 1 & 1 & 0.01 & 0.03 \\
Total & 5445 & 2759 & 99.94 & 99.94 \\
\hline
\end{tabular}

Catalogue No. [4679] [4682] [4683] [4688] [4692] [4693].

Table 8b. Shell frequencies: Trench B Stratum 5, Level 2

\begin{tabular}{lrrrr}
\hline \multicolumn{1}{c}{ Species } & $\begin{array}{c}\text { Total } \\
\mathrm{N}^{\mathbf{0}}\end{array}$ & MNI. & $\begin{array}{c}\text { Total } \\
(\%)\end{array}$ & $\begin{array}{c}\text { MNI. } \\
(\%)\end{array}$ \\
\hline Ostrea columbiensis & 2821 & 1411 & 68.20 & 66.71 \\
Chione subrugosa & 411 & 206 & 9.93 & 9.73 \\
Protothaca ecuadoriana & 758 & 379 & 18.32 & 18.00 \\
Cerithidea valida & 65 & 65 & 1.57 & 3.07 \\
Strophoceilus sp. & 1 & 1 & 0.02 & 0.04 \\
Strombus galeatus & 4 & 4 & 0.08 & 0.18 \\
Anadara tuberculosa & 25 & 13 & 0.60 & 0.61 \\
Anadara similis & 22 & 11 & 0.53 & 0.52 \\
Anadara grandis & 8 & 4 & 0.19 & 0.19 \\
Anadara obesa & 2 & 2 & 0.04 & 0.09 \\
Polinices sp. & 20 & 20 & 0.48 & 0.94 \\
Mactra augusta & 1 & 1 & 0.02 & 0.04 \\
Nassarius sp. & 1 & 1 & 0.02 & 0.04 \\
Crepidula marginalis & 1 & 1 & 0.02 & 0.04 \\
Total & 4140 & 2119 & 99.94 & 99.93 \\
\hline
\end{tabular}

Catalogue No. [4680] [4684] [4690] [4694] [982] [983] [1023] [1024].

Table 8c. Shell frequencies: Trench B Stratum 5, Level 3

\begin{tabular}{lrrrr}
\hline \multicolumn{1}{c}{ Species } & $\begin{array}{c}\text { Total } \\
\mathrm{N}^{\mathbf{0}}\end{array}$ & MNI. & $\begin{array}{c}\text { Total } \\
(\%)\end{array}$ & $\begin{array}{c}\text { MNI. } \\
(\%)\end{array}$ \\
\hline Ostrea columbiensis & 596 & 298 & 64.57 & 63.13 \\
Chione subrugosa & 76 & 38 & 8.23 & 8.05 \\
Protothaca ecuadoriana & 225 & 113 & 24.37 & 23.94 \\
Cerithidea valida & 5 & 5 & 0.54 & 1.07 \\
Anadara tuberculosa & 2 & 1 & 0.21 & 0.21 \\
Anadara similis & 2 & 1 & 0.21 & 0.21 \\
Anadara grandis & 4 & 2 & 0.43 & 0.43 \\
Polinices sp. & 9 & 9 & 0.97 & 1.91 \\
Mactra augusta & 2 & 1 & 0.21 & 0.21 \\
Cardita magastropha & 1 & 1 & 0.10 & 0.21 \\
Tellina ecuadoriana & 1 & 1 & 0.10 & 0.21 \\
Total & 923 & 472 & 99.94 & 99.98 \\
\hline
\end{tabular}

Catalogue No. [4681] [4685] [4691] [4695].
Table 8d. Shell frequencies: Trench B Stratum 5, Level 4

\begin{tabular}{lrrrr}
\hline \multicolumn{1}{c}{ Species } & $\begin{array}{c}\text { Total } \\
\mathrm{N}^{\mathbf{c}}\end{array}$ & MNI. & $\begin{array}{c}\text { Total } \\
(\%)\end{array}$ & $\begin{array}{c}\text { MNI. } \\
(\%)\end{array}$ \\
\hline Ostrea columbiensis & 645 & 323 & 53.57 & 53.03 \\
Chione subrugosa & 57 & 29 & 4.73 & 4.76 \\
Protothaca ecuadoriana & 453 & 227 & 37.62 & 37.27 \\
Anadara tuberculosa & 11 & 6 & 0.91 & 0.98 \\
Anadara similis & 18 & 9 & 1.49 & 1.47 \\
Anadara grandis & 11 & 6 & 0.91 & 0.98 \\
Anadara obesa & 2 & 1 & 0.16 & 0.16 \\
Polinices sp. & 4 & 4 & 0.33 & 0.65 \\
Mactra augusta & 1 & 1 & 0.08 & 0.16 \\
Crepidula marginalis & 1 & 1 & 0.08 & 0.16 \\
Tellina ecuadoriana & 1 & 1 & 0.08 & 0.16 \\
Total & 1204 & 609 & 99.96 & 99.78 \\
\hline
\end{tabular}

Catalogue No. [4713] [4714]

few days than would normally be deposited over a period of several months or even years of average inflow (Wells 2001:150). Conditions similar to these no doubt resulted in the deposition of uppermost stratum 6 at La Emerenciana, and the partial burial of the earthen mound.

Archaeological studies of ancient El Niños suggest they have a dramatic effect on the long-term cultural development of societies living in these coastal regions and those to the south (Moseley 1983, 1987; Moseley et al. 1981; Moore 1991; Keefer et al. 2003; Sandweiss 2003; Sandweiss et al. 2007, 2009). These data provide direct evidence that El Niño must be taken into account to interpretations of long-term cultural adaptation to both coastal and highland Andean regions (Keefer et al. 2003). Coastal stability and rate of geomorphic change are profoundly affected by El Niño cycles on a geological scale (Murphy 1939; Caviedes 1984; Gill and Rasmussen 1983).

The distinctive side effects of such climatic events include unpredictable downturns of aquatic resources. Mega-El Niños can be both beneficial and detrimental to a fishing economy. Since mollusk and fish are displaced into shallower, more accessible waters, there is an initial increase in "catches" of some species (Arntz 1986:18-20). Growth ring studies on shellfish and aquatic populations indicate an initial rapid growth followed by constricted growth rings on bivalves, and higher than normal densities of scallops and other invertebrates (Arntz 1986; Rollins et al. 1986, 1987). Intertidal and subtidal mussel beds and kelp forests are usually destroyed, resulting in widespread mortality that may sometimes 
take years to recover (Svenson 1946; Barber and Chavez 1983; Rasmussen and Wallace 1983; Arntz 1986:Figure 8). Such devastation is evident throughout the food chain (Holmgren et al. 2001).

El Niño can modify $\mathrm{pH}$ and algae levels, creating red tide as wetland lagoons and ponds turn to a maroon red color. After a period of several days, large numbers of fish and related aquatic fauna perish due primarily to lack of oxygen. Such sudden widespread mortality tempered a strong reliance upon such resources (Staller 1994). With the increased frequency of events during Middle and Late Formative times, the adaptive response favored a short-term dependence upon agricultural food crops. Modern analogues suggest that such events were central to scheduling and other adaptive adjustments to resource scarcity (Binford 1968, 1989, 2001; Flannery 1986). El Oro farmers refer to El Niño events as inviernos buenos (good winters) because after the rains subside, the hillsides are lush, green, and dense with vegetation, crops may be cultivated year-round, creating dramatically beneficial short-term consequences for agricultural specialization (Barber and Chavez 1983; Rasmussen 1985; Moseley 1983, 1987). The ecologically diverse environment of this region, appears to select for short-term survival strategies, e.g., increased specialization, and scheduling distinct collective strategies of resource exploitation, to take advantage of changing environmental and climatic conditions (Flannery 1973, 1986). The ancient adaptation was by necessity always flexible ranging from year round maritime research exploitation to periods of resource dependence upon food crops enough to withstand periods of scarcity or environmental stress brought by seemingly random periods of drought (Staller 2001a:213, figure 5). During the Middle Formative period c. 1450-1000 B.C. there were dramatic reductions in site size, population density as well as a total absence of ceremonial centers ${ }^{14}$.

14 Formative period ceremonial centers in coastal Ecuador are distinguished by earthen mounds of varying sizes (Staller 2000; Lunniss 2008). The earliest oval and circular earthen mounds pertain to Valdivia culture and have also been identified at sites of Real Alto, San Isidro, San Lorenzo del Mate (Staller 2001a; see also Lathrap et al. 1977; Marcos 1988; Marcos et al. 1976). Later ceremonial mounds and elite earthen platforms are of increasing scale and more geometric in form. Earthen platforms standing thirty meters high and sixty meters at the base pertaining to the Milagro Quevedo (AD 1100-1531) culture were identified in regional survey
Late Formative period settlement patterns suggest a greater dependence upon terrestrial plants, and a preference for floodplain settings however the coast is reoccupied marine resources intensively exploited for the rest of the pre-Hispanic sequence (Staller 1994, 2000). A total absence of prehistoric settlements along the shoreline during the Middle and Late Formative period c. $1400-300$ B.C. is suggested to be related to ecological transformations and geomorphological changes brought on by $\mathrm{El}$ Niño (see Table 3).

\section{Concluding Remarks}

In conclusion, the shell frequencies, stratigraphic, geomorphological, and geological evidence, as well as the formative settlement patterns, all point to the existence of ancient El Niño events in southern coastal Ecuador in the Early Formative. Direct and indirect evidence suggest repeated site abandonment at $\mathrm{La}$ Emerenciana was related such climatic events, and that human adaptation was permanently modified by their increased frequency over time. Initial site abandonment was in response to a Mega-El Niño event dated to ca. 2150 B.C. associated with fossil beach ridge formation and reoccupation ${ }^{14} \mathrm{C}$ dated 2200 to 1450 B.C., and final abandonment dated to ca. 1450 B.C. Final abandonment is associated with an earthquake and a short-lived reoccupation. These internally consistent supporting lines of evidence for a Mega-El Niño resulting in initial abandonment at La Emerenciana and fossil beach ridge formation tentatively dated to 4040 B.P. ( 4400 cal. B.P.) (Rodbell et al. 1999:figure 3). El Niño events associated with final site abandonment was also intense and destructive, possibly associated with, or closely followed by seismic activity resulting in permanent abandonment of the ceremonial center at $\sim 1450$ B.C. Changes in settlement patterning at this time involved a shift to knoll top settlement localities situated along the coastal streams. Perhaps the most dramatic geological evidence of this later event is further fossil beach ridge formations and the subsequent extinction of oysters, presumably an important source of protein, from this region for over a millennium.

north of Santa Rosa along the Buernavista River (Staller 1994). 


\section{Acknowledgments}

I wish to express my sincerest gratitude to the Fulbright Association in Washington D. C. for funding this research through a research scholarship and a dissertation improvement grant. I am deeply indebted to the late Olaf Holm, director of the Museo Antropológico del Banco Central del Ecuador in Guayaquil, and the Department of Anthropology of Southern Methodist University for their sponsorship and generous and enthusiastic support. Sincerest thanks to Alfred Siemens
(University of British Columbia) for sharing his insights on the coastal hydrology and geography. Special thanks and sincere appreciation to Sr. Hector Washco of Arenillas, for providing the initial scientific identification of the shellfish species, and access to many important Ecuadorian botanical and biological publications on the local ecology. All stratigraphic and archaeological interpretations of the various layers and archaeological context are the responsibility the author as is the presentation and interpretation of these data.

\section{References Cited}

Acosta-Solis, Misael

1959 Los Manglares del Ecuador. Instituto Ecuatoriano de Ciencias Naturales, Contribución Número 29. Quito, Ecuador.

1970 Geografía y ecología de las tierras áridas del Ecuador. Instituto Ecuatoriano de Ciencias Naturales, Contribución número 72, enero 1970, Quito, Ecuador.

Andrus, C. Fred T.; Daniel H. Sandweiss and Elizabeth J. Reitz 2008 Climate Change and Archaeology: The Holocene History of El Niño on the Coast of Peru. In Case Studies in Environmental Archaeology. E.J. Reitz, C.M. Scarry and S.J. Scudder (Eds.) pp. 143-157. Springer Science Business, London. Second Edition.

Arntz, Wolf E.

1986 The two faces of El Niño 1982-1983. Meeresforsch 31: 1-46.

Asaro, Frank; Ernesto Salazar; Helen V. Michel; Richard L. Burger and Fred Stross

1994 Ecuadorian Obsidian Sources Used for Artifact Production and Methods for Provenience Assignments. Latin American Antiquity 5(3): 257-277.

Barber, Richard T. and Francisco P. Chávez

1983 Biological consequences of El Niño. Science 222: 1203-1210.

Barazangi, Muawia and Bryan L. Isacks

1976 Spatial distribution of earthquakes and subduction of the Nazca plate beneath South America. Geology 4: 686-692. 1979 Subduction of the Nazca Plate beneath Peru, Evidence from spatial distribution of earthquakes. Geophysical Journal of the Royal Astronomical Society 57: 537-555.

Binford, Lewis R.

1968 Post-Pleistocene Adaptations. In New Perspectives in Archaeology. S.R. Binford, L.R. Binford (Eds.) pp. 5-33. Aldine, Chicago.

1989 Debating Archaeology. Academic Press, NY.

2001 Constructing frames of reference: an analytical method for archaeological theory building using hunter-gatherer and environmental data sets. University of California Press, Berkeley.

Cañadas-Cruz, Luis

1983 El Mapa Bioclimático y Ecológico del Ecuador. Publicado por el Banco Central del Ecuador, Quito.
Cane, Mark A.

1983 Oceanographic events during El Niño. Science 222: 1189-1194.

Carter, R.W.G.

1988 Coastal Environments. Academic Press, New York.

Caviedes, César N.

1975 El Niño 1972: Its climatic, ecological, human, and economic implications. Geographical Review 65: 493-509.

1984 El Niño. 1982-1983. Geographical Review 74: 267-290.

Chapman, Valentine J.

1976 Coastal Vegetation. Macmillan Co., New York.

1977 Introduction. In Wet Coastal Ecosystems. V.J. Chapman (Ed.) pp. 1-30. Ecosystems of the World Volume 1. Elsevier Scientific Publishing. Amsterdam.

Collier, Donald and John V. Murra

1943 Survey and Excavations in Southern Ecuador. Field Museum of Natural History Publication 528. Chicago.

Craig, Alan K. and Izumi Shimada

1986. El Niño flood deposits at Batán Grande, Northern Peru. Geoarchaeology 1: 29-38.

Currie, Elizabeth J.

1985 La cultura Jambelí con referencia particular al conchero Guarumal. In Memoria del Primer Simposio Europeo Sobre Antropología del Ecuador. S. E. Moreno Yáñez (Ed.). pp. 31-46. Instituto de Antropología cultural de la Universidad de Bonn. Ediciones Abya Yala. Quito, Ecuador.

Dillehay, Tom D. and Alan L. Kolata

2004 Long-term human response to uncertain environmental conditions in the Andes. Proceedings of the National Academy of Science USA 101: 4325-4330.

Dobson, C.H. and Alwyn H. Gentry

1991 Biological Extinctions in Western Ecuador. Annals of the Missouri Botanical Garden 78: 273-295.

Estrada, Emilio; Betty J. Meggers and Clifford Evans

1964 The Jambeli Culture of South Coastal Ecuador. Proceedings of the U.S. National Museum. Volume 115 (3492). Washington D.C.

Fagan, Brian

1999 Floods, Famines, and Emperors: El Niño and the Fate of Civilizations. Basic Books, New York.

Feininger, Thomas

1980 Ecologite and related high-pressure regional metamorphic rocks from the Andes of Ecuador. Journal of Petrology 21(1): 107-140. 
1982 The metamorphic "basement" of Ecuador. Geological Society of America Bulletin 93: 87-92.

Ferdon Jr., Edwin N.

1950 The climates of Ecuador. In Studies in Ecuadorian Geography School of American Research and Museum of New Mexico Bulletin 15: 35-63.

1981 Holocene mangrove formations on the Santa Elena Península, Ecuador. Pluvial indicators or ecological response to physiographic changes. American Antiquity 46: 619-626. Flannery, Kent V.

1973 The Origins of Agriculture. Annual Review of Anthropology 2: 271-310.

1986 Ecosystem Models and Information Flow. In Guilá Naquitz: Archaic Foraging and Early Agriculture in Oaxaca. K. V. Flannery (Ed.) pp. 19-28. San Diego: Academic Press. Gentry, Alwyn H.

1977 Endangered plant species and habitats of Ecuador and Amazonian Peru. In Extinction is Forever G. T. Prance and T. S. Elias (Eds.) pp. 136-149. New York Botanical Garden N.Y.

1986 Endemism in tropical versus temperate plant communities. In Conservation Biology. M. E. Soulé (Ed.) pp. 153-181. Sinauer Associates, Sunderland, MA.

1988 Patterns of plant community diversity on geographical and environmental gradients. Annals of the Missouri Botanical Garden 75: 1-52.

Gill, Allan and Eugene M. Rasmussen

1983 The 1982-83 climate anomaly in the equatorial Pacific. Nature 306: 229-234.

Gleaser, J. Douglas

1978 Global distributions of barrier islands in terms of their tectonic setting. Journal of Geology 86: 283-298.

Goudie, Andrew

1973 Duricrust in Tropical and Subtropical Landscapes. Clarendon Press, Oxford.

Hansen, B.C.S.; D.T. Rodbell; G.O. Seltzer; B. Leon; K.R. Young and M. Abbott

2003 Late-glacial and Holocene vegetational history from two sites in the western Mountain range of Southwestern Ecuador. Palaeogeography, Palaeoclimatology, Palaeoecology 194: 79-108.

Hayes, Miles O.

1975 Morphology of Sand Accumulation in Estuaries. In. Estuarine Research. L.E. Cronin (Ed.), pp. 3-22. Volume II. Academic Press, New York,

1979 Barrier island morphology as a function of tidal and wave regime. In Barrier Islands from the Gulf of St. Lawrence to the Gulf of Mexico. S. P. Leatherman (Ed.) pp. 1-27. Academic Press, New York.

Hocquenghem, Anne-Marie

1991 Frontera entre "Áreas Culturales" nor y centroandinas en los valles y la costa del extremeo norte peruano. Bulletin de l'Institut Français d'Etudes Andines 20 (2): 309-348.

1993 Rutas de entrada del mullu en el extremo norte del Perú. Bulletin del 'Institut Français d'Etudes Andines 22 (3): 701-719.

Hocquenghem, Anne-Marie; Jaime Idrovo; Peter Kaulicke and Dominque Gomis

1993 Bases del intercambio entre las sociedades norperuanas y surecuatorianas: una zona de transición entre 1500 a.C. y 600 d.C. Bulletin de l'Institut Français d'Etudes Andines 22 (2): 443-466.
Holliday, Vance T.

1990 In Archaeological Geology of North America P. Lasca and J. Donahue (Eds): 525-540. Geological Society of America Centennial Special Volume 4.

Holmgren, M.; M.; Scheffer; E.; Ezcurra; J.R.; Gutiérrez and G.M.J. Mohren

2001 El Niño effects on the dynamics of terrestrial ecosystems. Trends on Ecology and Evolution 16: 89-94.

Hou, D.

1960 A review of the genus Rhizophora with special reference to the Pacific species. Blumea 10: 625-634.

Isaacson, John S.

1994 Volcanic sediments in archaeological contexts. In Regional Archaeology in Northern Ecuador, Volume 1: Environment, Cultural Chronology and Prehistoric Subsistence in the Jama River Valley. J. A. Zeidler, and D. Pearsall (Eds.) pp. 131-140. University of Pittsburgh, Memoirs in Latin American Archaeology $\mathrm{N}^{\circ}$ 8. Pittsburgh,

Jordán, Teresa E.; Bryan L. Isaaks; Richard W. Allmendinger; Jon A. Brewer; Víctor A. Ramos; Clifford J. Ando

1983 Andean tectonics related to geometry of subducted Nazca plate. Geological Society of America, Bulletin 94: 341-361.

Joukowsky, Martha

1980 A Complete Manual of Field Archaeology Tools and Techniques of Field Work for Archaeologists. Prentice-Hall Inc. Englewood Cliffs, New Jersey 07632.

Keefer, David K.; Michael E.; Moseley and Susan D. de France 2003 A 38000-year record of floods and debris flows in the Ilo region of southern Peru and its relation to El Niño events and great earthquakes. Palaeogeography, Palaeoclimatology, Palaeoecology 194: 41-77.

Keefer, David K. and Michael E. Moseley

2004 Southern Peru desert shattered by the great 2-1 earthquake: Implications for paleoseismic and paleo-El Niño-Southern Oscillation records. Proceedings of the National Academy of Sciences USA 101(30): 10878-10883.

Kerr, Richard A.

1999 El Niño Grew Strong as Cultures were Born. Science 283: 467-468.

Lanning, Edward P.

1965 Early Man in Peru. Scientific American 213: 68-76.

Lathrap, Donald W.; Jorge G. Marcos and James E. Zeidler

1977 Real Alto: An Ancient Ceremonial Center. Archaeology 30(1): 2-13.

Lunniss, Richard

2008 Where the Land and Ocean Meet: The Engoroy Phase Ceremonial Site at Salango, Ecuador. In Pre-Columbian Landscapes of Creation and Origin. J. E. Staller (Ed.) pp. 203-248. Springer, New York.

Marcos, Jorge G.

1988 Real Alto: la historia de un centro ceremonial Valdivia. Biblioteca Ecuatoriana de Arqueología. Primera Parte ESPOL Guayaquil. Corporación Editora Nacional.

Marcos, Jorge G.; Donald W. Lathrap and James E. Zeidler 1976 Ancient Ecuador revisited. Field Museum of Natural History Bulletin 47(6): 3-8. Chicago.

McPhaden, M.J.

1999 Genesis and Evolution of the 1997-1998 El Niño. Science 283: 950-954.

McPhaden, M.J. and J. Picaut

1990 El Niño-Southern Oscillation Displacements of the Western Equatorial Pacific Warm Pool. Science 250 Reports, 1385-1388. 
Meggers, Betty J.; Clifford Evans Jr. and Emilio Estrada 1965 Early Formative of Coastal Ecuador: The Valdivia and Machalilla Phases. Smithsonian Contributions in Anthropology. Volume 1. Washington D.C.

Middleton, Gerard W.

1973 Johannes Walther's law of the correlation of facies. Geological Society of America Bulletin 84: 979-988.

Momsen Jr., Richard P.

1968 Precipitation Patterns of West-Central Ecuador. Revista Geografica 69: 91-105.

Moore, Jerry D.

1991 Cultural responses to environmental catastrophes: Post El Niño subsistence on the prehistoric North Coast of Peru. Latin American Antiquity 2(1): 27-47.

Moore, Jerry; Daniel D. Manrique and Eva Pajuelo, 2008 Excavaciones en Santa Rosa y Uña de Gato. Informe Final de Proyecto Arqueológico Tumbes. Ms. Lima

Moreano, H.R.

1984 The weakening of the 1982-83 El Niño in Ecuadorian waters. Tropical Ocean-Atmosphere Newsletter 28, $13 \mathrm{f}$.

Moseley, Michael E.

1983 The Good Old Days Were Better: Agrigarian Collapse and Tectonics. American Anthropologist 85, 773-779.

1987 Punctuated Equilibrium: Searching the Ancient Record for El Niño. The Quarterly Review of Archaeology 1987, 7-10.

Moseley, Michael E.; Robert A. Feldman and Charles R. Ortloff 1981 Living with Crisis: Human Perception of Process and Time. In Biotic Crises in Ecological and Evolutionary Time. M. H. Nitecki (Ed.) pp. 231-267. Academic Press, New York. Moy, Christopher M.; Geoffrey O. Seltzer; Donald T. Rodbell and David M. Anderson

2002 Variability of El Niño Southern Osscillation activity at millennial timescales during the Holocene epoch. Nature 420: $162-165$.

Murphy, Robert C.

1939 The Littoral of Pacific Colombia and Ecuador. Geographical Review 29: 1-33.

Murray, Stephen; Dennis Conlon; Absornsuda Siripong and Jose Santoro

1975 Circulation and salinity distribution in the Río Guayas Estuary, Ecuador. In Estuarine Research Volume II. L. E. Cronin (Ed.): 345-363. Academic Press N.Y.

Myra Keen, Angeline

1971 Sea Shells of Tropical West America. Marine Mollusks from Baja California to Peru. Second Edition. Stanford Press, Stanford.

Norton, Presley

1982 Preliminary observations on Loma Alta, an early Valdivia midden in Guayas Province, Ecuador. In Primer Simposio de Correlaciones Antropológicas Andino-Mesoamericano. C. Zevallos-Menéndez and P. Norton (Eds.) pp. 101-120. Salinas, Ecuador. Junio, 1971. ESPOL, Guayaquil, Ecuador. Nummedal, Dag

1983 Barrier Islands. In Handbook of Coastal Processes and Erosion. P. Komar (Ed.) pp. 77-121. CRC Press. Taylor \& Frances Group.

Olsson, Alex A.

1961 Mollusks of tropical Eastern Pacific, Particularly from the Southern Half of the Panamic-Pacific faunal Province (Panama to Peru). Panamic-Pacific Pelecypoda. Paleontological Research Institution, N.Y.: Ithaca.
Parker III, Theodore A. and John L. Carr (Eds.)

1992 Status of Forest Remnants in the Cordillera de la Costa and Adjacent Areas of Southwestern Ecuador. Rapid Assessment Program (RAP Working Papers 2) Conservation International.

Parsons, Jeffrey R.

1974 The Development of a Prehistoric Complex Society: A regional perspective of the Valley of Mexico. Journal of Field Archaeology 1: 81-108.

Paulsen, Alice C.

1974 The Thorny Oyster and the Voice of God: Spondylus and Strombus in Andean Prehistory, American Antiquity 39: 597-607.

Philander, S.G.H

1983 Anomalous El Niño of 1982-1983. Nature 305: 16

1989 El Niño and La Niña. American Scientist 77: 451-459

1998 Is the Temperature Rising? Princeton University Press, Princeton, New Jersey

Rasmussen, Eugene M.

1985 El Niño and Variations in Climate. American Scientist 73 (2): 168-177.

Rasmussen, Eugene M. and John M. Wallace

1983 Meteorological aspects of El Niño/Southern Oscillation. Science 222: 1195-1202.

Richardson, James B.

1983 The Chira beach ridges, sea level change and the origins of marine economy on the Peruvian coast. Annuals of the Carnegie Museum 52 (11): 265-276.

Ridgely, Robert S. and Paul J. Greenfield

2001 The Birds of Ecuador. Volume 1. Status, Distribution, and Taxonomy. Forward by F.B. Gill. Cornell University Press. Ithaca, NY.

Rodbell, Donald T.; Geoffrey O. Seltzer; David M. Anderson;

Mark B. Abbott; David B. Enfield and Jeremy H. Newman 1999 An 15,000-Year Record of El Niño-Driven Alluviation in Southwestern Ecuador. Science 283: 516-520.

Rodbell, Donald T.; Stefan Bagnato; Jeffrey C. Nebolini; Geoffrey

O. Seltzer and Mark B. Abbott

2002 A Late Glacial-Holocene Tephrachronology for Glacial Lakes in Southern Ecuador. Quaternary Research 57: 343-354.

Rollins, Harold B.; Daniel H. Sandweiss and Judith Rollins

1986 Effect of the 1982-1983 El Niño on bivalve mollusks. National Geographic Review 2: 106-112.

1987 Growth increment and stable isotope analysis of marine bivalves: Implications for the geoarchaeological record of El Niño. Geoarchaeology 2(3): 181-197.

Sandweiss, Daniel H.

1986 The beach ridges at Santa, Peru: El Niño, uplift, and prehistory. Geoarchaeology 1: 17-28.

2003. Terminal Pleistocene through Mid-Holocene archaeological sites as paleoclimatic archives for the Peruvian coast. Palaeogeography, Palaeoclimatology, Palaeoecology 194: 23-40.

Sandweiss, Daniel H.; Harold B.Rollins and James B. Richardson III

1983 Landscape alteration and prehistoric human occupation on the north coast of Peru. Annuals of the Carnegie Museum 52: $277-298$.

Sandweiss, Daniel H.; James B. Richardson III; Elizabeth

J. Reitz; Harold B. Rollins and Kirk A. Maasch

1996 Geoarchaeological evidence from Peru for a 5000 Year B.P. onset of El Niño. Science 273: 1531-1533. 
Sandweiss, Daniel H.; Kirk A. Maasch; C. Fred T. Andrus; Elizabeth J. Reitz; Mary Riedinger-Whitmore; James B.; Richardson III and Harold B. Rollins

2007 Mid-Holocene climate and culture change in coastal Peru. In Climate Change and Cultural Dynamics: A Global Perspective on Mid-Holocene Transitions D. G. Anderson, K. A. Maasch, D. H. Sandweiss (Eds). Elsevier, San Diego. Sandweiss, Daniel H.; Ruth Shady Solís; Michael E.; Moseley; David K. Keefer and Charles R. Ortloff

2009 Environmental change and economic development in coastal Peru between 5,800 and 3,600 years ago. Proceedings of the National Academy of Sciences USA 106: 1359-1363. Satterlee, Dennis R.; Michael E.; Moseley; David K.; Keefer and Jorge E. Tapia A.

2001 The Miraflores El Niño Disaster: Convergent catastrophes and prehistoric agrarian change in southern Peru. Andean Past 6: 95-116.

Shackley, M.L.

1975 Archaeological sediments; A survey of analytical methods. London: Butterworths.

Staller, John E.

1992/93 El montículo ceremonial en el sitio de La Emerenciana en la costa sur del Ecuador y su significación del desarrollo de complejidad en la costa oeste sudamericana. Cuadernos de Historia y Arqueología Nos. 46-47: 14-37. Publicación de la Casa la Cultura Ecuatoriana. Benjamín Carrión, Núcleo del Guayas. Guayaquil.

1994 Late Valdivia Occupation in El Oro Province Ecuador: Excavations at the Early Formative Period (35001500 B.C.) site of La Emerenciana. Ph.D. Dissertation, Department of Anthropology, Southern Methodist University, Dallas, Texas. UMI, Ann Arbor.

1996 El sitio Valdivia tardío de La Emerenciana en la costa sur del Ecuador y su significación del desarollo de complejidad en la costa de sudamericana. Cuadernos de Historia y Arqueología Nos. 48-50: 65-118. Edición en homenaje a Olaf Holm. Publicación de la Casa la Cultura Ecuatoriana. Benjamín Carrión, Núcleo del Guayas, Guayaquil.

2000 Political and prehistoric frontiers: How history influences our understanding of the past. In The Entangled Past: Integrating History and Archaeology. M. Boyd, J. Erwin, M. Hendrickson (Eds.) pp. 242-258. Proceedings of the 30th Annual Chacmool Conference Calgary, Alberta. The Archaeological Association of The University of Calgary, Alberta.

2001a Reassessing the chronological and developmental relationships of the Formative of coastal Ecuador. Journal of World Prehistory 15(2): 193-256.

2001b The Jelí Phase Complex at La Emerenciana, a late Valdivia site in southern El Oro Province, Ecuador. Andean Past 6: 117-174.

2003 An examination of the paleobotanical and chronological evidence for an early introduction of maize (Zea mays L.) into South America: A response to Pearsall. Journal of Archaeological Science 30(3): 373-380.

2007 Un reevaluación del papel de la ideología en el intercambio de larga distancia temprano y a los orígenes de la civilización andina. In "II Congreso Ecuatoriano de Antropología y Arqueología: Balance de la última década: aportes, retos y nuevos temas". F. García (Ed.) pp. 511-548. Tomo 1. Abya Yala, Quito.
2010 Maize Cobs and Cultures: History of Zea mays L. Springer, Berlin; Hiedelberg.

Staller, John E. and Robert G. Thompson

2000 Reconsiderando la Introducción del Maíz en el Occidente de América del Sur. Bulletin de l'Institut Français d'Etudes Andines 30(1): 123-156. Lima.

2002 A multidisciplinary approach to understanding the initial introduction of maize into coastal Ecuador. Journal of Archaeological Science 29(1): 33-50.

Stein, Julie K.

1990 Archaeological stratigraphy. In Archaeological Geology of North America. N.P. Lasca and J. Donahue (Eds). pp. 513523. Centennial Special Volume 4. The Geographic Society of America.

1992a The analysis of shell middens. In Deciphering a Shell Mound. J. K. Stein (Ed.) pp. 1-24. Academic Press, San Diego. 1992b Interpreting stratification of a shell midden. In Deciphering a Shell Mound. J. K. Stein (Ed.) pp. 71-93. Academic Press, San Diego.

2001 Archaeological sediments in cultural environments. In Sediments in Archaeological Context. J. K. Stein, W.R. Farrand (Eds.) pp. 1-29. The University of Utah Press, Salt lake City.

Struiver, M.; P.J. Reimer; E. Bard; J.W. Beck; G.S. Burr; A.K. Hugan; B. Kromer; M.S. McCormac; J. van der Plicht and M. Spurk 1998 INTCAL98 Radiocarbon Age Calibration, 24000-0 cal. BP. Radiocarbon 40: 1041-1084.

Svenson, Henry K.

1946 Vegetation of the Coast of Ecuador and Peru and its Relationship to that of the Galapagos Islands. Contribution No. 104. N.Y.: Brooklyn Botanic Garden.

Swift, Donald J.P.

1975 Barrier island genesis: Evidence from the Central Atlantic shelf, eastern U.S.A. Sedimentary Geology 14: 1-43.

1976 Coastal Sedimentation. In Marine Sediment Transport and Environmental Management. Stanley, D. J., Swift, D. J. P. (Eds.) pp. 255-310. John Wiley, New York.

Swift, Donald J.P.; Alan William Niederoda; Christopher E. Vincent and Tom S. Hopkins

1985 Barrier Island Evolution, Middle Atlantic Shelf, U.S.A. Part I: Shoreface dynamics. Marine Geology 46: 331-361.

Thayer, Victoria G. and Richard Barber

1984 At sea with El Niño Natural History 10: 4-12.

Thompson, Robert G. and John E. Staller

2001 An analysis of opal phytoliths from food residues of selected sherds and dental calculus from excavations at the site of La Emerenciana, El Oro Province, Ecuador. Phytolitherian, Bulletin of the Society for Phytolith Research. Vol.13 no. 2\&3: 8-16.

Troll, Carl

1968 The cordilleras of the tropical Americas: Aspects of climatic, phytogeographical, and agrarian ecology. In Geoecology of the Mountainous Regions of the Tropical Americas. C. Troll (Ed.) pp. 13-56. Dümmlers Verlag: Colloquiom Geographicum Band 9.

Tykot, Robert H. and John E. Staller

2002 On the Importance of Early Maize Agriculture in Coastal Ecuador: New Data from the Late Valdivia Phase site of La Emerenciana. Current Anthropology 43: 666-677.

Ubelaker, Douglas H. and Erica Bubniak Jones

2002 Formative Period Human Remains from Coastal Ecuador: La Emerenciana Site (OOSrSr-42). Journal of the Washington Academy of Sciences 88(2): 59-72. 
Uhle, Max

1920a. Los principios de las antiguas civilizaciones peruanas. Boletín de la Sociedad Ecuatoriana de Estudios Históricos, 4 (12): 448-458.

1920b. Los principios de la civilización en la sierra peruana. Boletín de la Sociedad Ecuatoriana de Estudios Históricos, 4 (13-14): 44-56, 7 plates.

1922a The excavations at Cañar. The Panamerican Magazine, 34, No. 4. London.

1922b Sepulturas ricas de oro en la provincia del Azuay. Boletín de la Academia Nacional de Historia, 4 (9): 108-114.

1928 Desarollo y origen de las civilizaciones americanas. Proceedings, twenty-third International Congress of the Americanists: 31-43.

1929 Estado actual de la prehistoria ecuatoriana. Quito.

1936 Las antiguas civilizaciones del Ecuador y Perú. Boletín de la Academia Nacional de Historia 13(36-39).

Valentine, K.W.G. and J. B. Dalrymple

1976 Quaternary Buried Paleosols: A Critical Review. Quaternary Research 6: 209-222.

Van der Merwe, Nik; Julia A. Lee-Thorp. and J. Scott Raymond 1993 Light, Stable Isotopes and the subsistence base of formative cultures at Valdivia, Ecuador. In Prehistoric Human Bone Archaeology at the Molecular Level, edited by J. B. Lambert and G. Grupe, pp.63-97. Springer Verlag Ltd.

Vuille, Mathias; Raymond S. Bradley and Frank Keimig

2000 Climate variability in the Andes of Ecuador and its relation to tropical Pacific and Atlantic sea surface temperature anomalies. Journal of Climate 13: 2520-2535.

Wells, Lisa E.

1987 An alluvial record of El Niño events from northern coastal Peru. Journal of Geophysical Research 92(C13) 14: $463-14,470$.
2001 Archaeological Sediments in Coastal Environments. In Sediments in Archaeological Context. J. K. Stein and W. R. Farrand (Eds.) pp. 149-182. The University of Utah Press, Salt Lake City.

Wernstedt, Fredrick L.

1972 World Climatic Data. Climatic Data Press.

Wolf, Theodore

1892 Geografía y Geológica del Ecuador. Leipzig.

Woods, William I.

1977 The quanitative analysis of soil phosphate. American Antiquity 42(2): 248-252.

Wrtki, Klaus

1973 Telecommunication in the equatorial Pacific Ocean. Science 180, 66-68.

1979 El Niño. La Recherche 106: 1212-1220.

1982 The southern oscillation, ocean-atmosphere interaction and El Niño. Marine Technological Society Journal $16(3)$.

Wrtki, Klaus; Edward Satroup; William Patzert; Robert Williams and William Quinn

1976 Predicting and observing El Niño. Science 191: 343-346.

Willey, Gordon R.

1953 Prehistoric settlement patterns in the Virú Valley, Peru. Bureau of American Ethnology, Bulletin 155, Smithsonian Institution, Washington, D. C.

1962 The great art styles and the rise of Pre-Columbian civilization. American Anthropologist 64(1): 1-14.

Zeidler, James A.

1988 Feline imagery, stone mortars, and Formative Period interaction spheres in the Northern Andean Area. Journal of Latin American Folklore 14 (2): 243-283. 